This document is confidential and is proprietary to the American Chemical Society and its authors. Do not copy or disclose without written permission. If you have received this item in error, notify the sender and delete all copies.

\title{
High-Resolution Structural Characterization of a Heterogeneous Biocatalyst Using Solid-State NMR
}

\begin{tabular}{|r|l|}
\hline Journal: & The Journal of Physical Chemistry \\
\hline Manuscript ID & jp-2016-115754 \\
\hline Danuscript Type: & Article \\
\hline Complete List of Authors: & $\begin{array}{l}\text { Varghese, Sabu; Lancaster University, Department of Chemistry } \\
\text { Halling, Peter; Univ Strathclyde, Pure \& Applied Chemistry } \\
\text { Häussinger, Daniel; Universität Basel, Chemie } \\
\text { Wimperis, Stephen; Lancaster University, Department of Chemistry }\end{array}$ \\
\hline
\end{tabular}

\section{SCHOLARONE \\ Manuscripts}




\section{INTRODUCTION}

The immobilization of proteins and living cells on nonbiological surfaces plays a central role in a wide range of important technological applications, including industrial biocatalysis, drug delivery, medical diagnosis, wastewater treatment, biosensing, and textile and detergent manufacture. ${ }^{1}$ In particular, immobilized enzymes are widely used in such diverse applications as the conversion of biomass to fuel, the synthesis of fine chemicals, pharmaceutical production, and the food and cosmetics industries. ${ }^{2}$ Compared with homogeneous enzyme catalysis in solution, heterogeneous enzyme catalysis is advantageous as the immobilized catalytic system can be easily separated from the reaction mixture and so used repeatedly. ${ }^{3}$ An immobilized enzymatic system consists usually of an enzyme, the supporting matrix, and the mode of attachment between the enzyme and the support. The enzymes can be attached to different inorganic and organic supports by interactions ranging from physical adsorption, through ionic contacts, to stable covalent bonds. ${ }^{2}$ From the many different methods available for enzyme immobilization on various surfaces, covalent immobilization provides the most robust means of immobilization as leaching effects are minimized. ${ }^{2}$

Among the various inorganic and organic supports available, mesoporous silica has gained considerable attention for immobilization of enzymes and catalysts due to its unique properties, including large surface area, tunable particle size and pore diameter. Furthermore, biocompatibility, the robustness of its structure and morphology towards $\mathrm{pH}$ and extreme temperatures, and the various possibilities of activating the surface and internal pores for different applications make mesoporous silicas interesting candidates for immobilization studies. ${ }^{4}$
Although there have been extensive studies of the catalytic activity of enzymes immobilized by a wide range of methods, ${ }^{5-6}$ rational design of the heterogeneous biocatalytic system still remains a considerable challenge as very little is known about the state of the enzyme, support and the linker upon immobilization. Solid-state magic-angle spinning (MAS) NMR is an ideal tool for studying such heterogeneous systems, as the system under consideration does not require any long-range order. Furthermore, solidstate NMR has been successfully employed for studying complex biological systems that are not accessible by X-ray crystallography or solution-state NMR. ${ }^{7}$ MAS NMR has been used previously to study a variety of immobilized enzymes and supports. ${ }^{8.19}$ However, most of these research studies were focussed mainly on studying the support systems and/or the biochemical characterization of the biocatalytic system. There have also been quite extensive highresolution MAS NMR studies of proteins and peptides involved in biomineralisation, adsorbed on the surfaces of the inorganic materials whose growth they control..$^{20-25}$ But there have so far only been a few studies of signals from enzyme molecules immobilized on supports as biocatalysts. Fragai et al showed high-resolution twodimensional spectra of ${ }^{13} \mathrm{C}$ and ${ }^{15} \mathrm{~N}$ labelled enzymes entrapped in peptide-templated silica gel particles. ${ }^{26}$ This report indicated that the three-dimensional structures of the enzymes were hardly affected by immobilization. Subsequent work by the same group ${ }^{27}$ demonstrated enhanced sensitivity using dynamic nuclear polarisation $^{28}$ and explored the feasibility of ${ }^{1} \mathrm{H}$-detected measurements. ${ }^{29}$ Natural abundance silica-entrapped lysozyme ${ }^{13} \mathrm{C}$ signals were also detectable using DNP-enhancement. ${ }^{28}$ Furthermore, RamirezWong et al. used ${ }^{1} \mathrm{H}$ signals to determine the ratio of lysozyme to chitosan in a deposited layered conjugate. ${ }^{12}$ 
Very recently, MAS NMR has been successfully employed to characterize a covalently immobilized enzymatic system consisting of a model enzyme $\alpha$-chymotrypsin, mesoporous silica as the matrix, and (3-glycidyloxypropyl)trimethoxysilane (GLYMO) as the covalent linker. ${ }^{30}$ However, this natural abundance MAS NMR study of covalently immobilized chymotrypsin was hampered by poor NMR sensitivity, making it impossible to obtain detailed structural and dynamic information from the immobilized enzyme.

In this research work, we report finer structural details of a model enzyme, human carbonic anhydrase II (hCA II) in the isotopically labelled $\left({ }^{15} \mathrm{~N}\right)$ state before and after covalent immobilization on epoxy-functionalized silica. Human carbonic anhydrase II is a relatively low molecular weight ( $29 \mathrm{kDa}, 260$ residues $)$ enzyme suitable for catalyzing the reversible hydration of carbon dioxide. The structure of the enzyme has been solved by X-ray crystallography ${ }^{31}$ and extensively studied by $\mathrm{NMR}^{32-34}$ and is therefore an ideal candidate for covalent immobilization studies using MAS NMR. Since the size of the protein $(\sim 29 \mathrm{kDa})$ still poses challenges for NMR to provide atomic-level structural information, hCA II samples were prepared in natural abundance and isotopically enriched $\left({ }^{15} \mathrm{~N}\right)$ states (uniformly labelled samples termed hereafter as $\left[\mathrm{U}-{ }^{15} \mathrm{~N}\right] /$ hCA II). Furthermore, the samples were selectively ${ }^{15} \mathrm{~N}$ labelled for the most abundant amino acid residue leucine (termed hereafter as $\left[{ }^{15} \mathrm{~N} \mathrm{Leu}\right] / \mathrm{hCA}$ II) to reduce problems arising from spectral degeneracy in multi-dimensional MAS NMR experiments. Our results show that MAS NMR can be successfully employed to characterize the support, linker and the enzyme before and after immobilization and a simple schematic model of the complete heterogeneous biocatalytic system can be proposed.

\section{MATERIALS AND METHODS}

Protein Expression, Purification and Characterization

The hCA II plasmid (pACA) used for the production of hCA II mutants was a generous gift from Carol A. Fierke (University of Michigan, USA).$^{35}$ hCA II double mutants were prepared by sitedirected mutagenesis. The wild-type hCA II plasmid was used as the initial template for the first mutation (C206S) while plasmids already containing the C206S mutation were used for the final double mutants. The site-directed mutagenesis steps were carried out according to the procedure described by Zheng et al. ${ }^{36}$ All constructs were overexpressed in $\left[\mathrm{U}_{-}{ }^{15} \mathrm{~N}\right] / \mathrm{hCA}$ II and in $\left[{ }^{15} \mathrm{~N}\right.$ Leu]/hCA II form; the S50C-C206S construct - all expressions were carried out in E.coliBL21(DE3)pLysS cells by standard methods. Selective ${ }^{15} \mathrm{~N}$ Leu labelling was achieved by using a minimal medium and a mixture of 18 unlabelled amino acids (all standard amino acids with the exception of Leu and Asn) as the main culture medium. Simultaneously with IPTG induction, $60 \mathrm{mg} / \mathrm{L}$ ${ }^{15} \mathrm{~N}$-labelled Leu was added. The harvested cells were lysed by three freeze thaw cycles and resuspended in $25 \mathrm{~mL}$ of lysis buffer $(50$ $\mathrm{mM}$ Tris- $\mathrm{SO}_{4}, \mathrm{pH}$ 8.0, $50 \mathrm{mM} \mathrm{NaCl}, 0.5 \mathrm{mM} \mathrm{ZnSO}_{4}, 1 \mathrm{mM}$ DTT and $10 \mu \mathrm{g} / \mathrm{mL}$ PMSF). The suspension was shaken vigorously (300 $\mathrm{rpm}$ ) at room temperature (RT) for $30 \mathrm{~min}$ then deoxyribonuclease I (DNaseI, $1 \mu \mathrm{g} / \mathrm{L}$ ) was added and the mixture was shaken for another $30 \mathrm{~min}$. The lysate was centrifuged at $16880 \mathrm{~g}$ for $30 \mathrm{~min}$ at $4{ }^{\circ} \mathrm{C}$. The supernatant was recovered and the pellet was resuspended twice further in $25 \mathrm{~mL}$ lysis buffer. The total $75 \mathrm{~mL}$ solution from the extraction was filtered through a $0.45 \mu \mathrm{m}$ filter and used directly for affinity chromatography. Affinity chromatography was performed using $25 \mathrm{~mL}$ of 4-(2-aminoethyl)benzenesulfonamide agarose resin packed into a XK16 column (GE Healthcare, Glatt- brugg, Switzerland). The column was equilibrated with 5 column volume (CV) activity buffer ( $50 \mathrm{mM}$ Tris- $\mathrm{SO}_{4}, \mathrm{pH} 8.0,0.5 \mathrm{mM}$ $\left.\mathrm{ZnSO}_{4}, 1 \mathrm{mM} \mathrm{DTT}\right)$ and the protein in $75 \mathrm{~mL}$ of lysis buffer was loaded onto the column at a slow flow rate $(1 \mathrm{~mL} / \mathrm{min})$. Then the column was washed with $5 \mathrm{CV}$ of wash buffer $\left(50 \mathrm{mM} \mathrm{Na}_{2} \mathrm{SO}_{4}, 50\right.$ $\mathrm{mM} \mathrm{NaClO}_{4}, 25 \mathrm{mM}$ Tris-SO 4 , $\mathrm{pH} 8.8,1 \mathrm{mM} \mathrm{DTT}$ ) and the protein was eluted with $10 \mathrm{CV}$ of elution buffer $\left(200 \mathrm{mM} \mathrm{NaClO}_{4}, 100\right.$ $\mathrm{mM}$ NaAc, pH 5.6, $1 \mathrm{mM}$ DTT). $10 \mathrm{~mL}$ fractions were collected and those containing the protein (detected by UV absorption) were pooled and dialyzed at $4{ }^{\circ} \mathrm{C}$ against activity buffer for $12 \mathrm{~h}$, followed by deionized $\mathrm{H}_{2} \mathrm{O}$ for $24 \mathrm{~h}$, and finally against ultrapure water for another $24 \mathrm{~h}$. Dialysis buffer contained $100 \mu \mathrm{M}$ DTT and was exchanged at least three times a day. The resulting solution was frozen in liquid nitrogen and lyophilized. The resulting protein was stored at $4{ }^{\circ} \mathrm{C}$. The proteins were all characterized by SDS-PAGE ( $12 \%$ acrylamide, $200 \mathrm{~V}, 1.5 \mathrm{~h}$ ) and by ESI-MS on a Bruker Daltonics microTOF instrument. Additionally, solution NMR spectroscopy was carried out on a Bruker Avance III HD spectrometer operating at $600 \mathrm{MHz}$ proton frequency, equipped with a cryogenic QCI probe ${ }^{1} \mathrm{H} /{ }^{13} \mathrm{C} /{ }^{15} \mathrm{~N} /{ }^{19} \mathrm{~F}$ with $\mathrm{z}$-axis pulsed field gradient.

\section{Synthesis of Epoxy-Functionalized Silica}

The epoxy-activated silica (epoxy-silica) was prepared according to previously established protocols. ${ }^{37}$ The SP-100-15-P Daiso silica gel (pore size of $100 \AA$, $5 \mathrm{~g}$ ) was calcined at $200{ }^{\circ} \mathrm{C}$ under vacuum for $24 \mathrm{~h}$. The freshly activated dry silica was then suspended in dry toluene $(80 \mathrm{ml})$ and degassed by sonication under vacuum for 30 minutes. A ten-fold theoretical excess of GLYMO was added and the mixture was heated to reflux for $4 \mathrm{~h}$. The amount of GLYMO added to the reaction mixture was calculated ${ }^{38}$ based on the specific surface area of silica $\left(452 \mathrm{~m}^{2} / \mathrm{g}\right)^{\mathrm{a}}$ and the wetting area of GLYMO $\left(330 \mathrm{~m}^{2} / \mathrm{g}\right)$. After the completion of the reaction, the reaction mixture was cooled to room temperature. The resulting solid was washed with $250 \mathrm{ml}$ of dry toluene, $125 \mathrm{ml}$ of THF, and $250 \mathrm{ml}$ of methanol, and finally dried under vacuum at $150{ }^{\circ} \mathrm{C}$ for $24 \mathrm{~h}$. The epoxide content grafted onto the silica surface (epoxy equivalent weight, EEW) was determined by nonaqueous titration of the oxirane groups according to the modified Dubertaki method. ${ }^{39}$

\section{Covalent Immobilization of hCA II and Enzymatic} Assays

Covalent immobilization of hCA II on epoxy-silica was performed according to the previously established methods..$^{40}$ Human carbonic anhydrase II was dissolved in $1.88 \mathrm{M}$ ammonium sulfate, $0.010 \mathrm{M}$ potassium phosphate $(\mathrm{pH} 8.0$ ) resulting in $10 \mathrm{mg} / \mathrm{mL}$ protein solution. A $1 \mathrm{~mL}$ volume of the above solution was mixed with $100 \mathrm{mg}$ of epoxy-silica in a $5 \mathrm{~mL}$ capped vial. The mixture was gently mixed for $40 \mathrm{~h}$ at room temperature using an orbital rotator. The modified support was recovered by centrifugation and washed twice successively with $1 \mathrm{~mL}$ of $0.010 \mathrm{M}$ potassium phosphate $(\mathrm{pH}$ 7.0 ) and $2 \mathrm{~mL}$ of $0.010 \mathrm{M}$ sodium acetate ( $\mathrm{pH} 4.5$ ) containing 0.3 $\mathrm{M}$ sodium chloride. Finally, the immobilized enzymatic system was equilibrated with $2 \mathrm{~mL}$ of $0.10 \mathrm{M}$ potassium phosphate ( $\mathrm{pH} 6.0$ ). The amount of protein covalently immobilized on the epoxy-silica was calculated indirectly from the difference between the amount

${ }^{a}$ Based on the information provided by the supplier of bare silica (Daiso Chemical Co. Ltd, Japan). 
of protein added initially for immobilization and the amount of the enzyme in the supernatant after immobilization (including washings). Quantification of the protein was carried out using a spectrophotometer based on the colorimetric method of Bradford. ${ }^{41}$ The esterase activity of the hCA II was determined spectrophotometrically using p-nitrophenyl acetate (p-NPA) as a substrate, as described elsewhere. ${ }^{42}$ Briefly, the assay system comprised $0.2 \mathrm{~mL}$ of hCA II solution $(0.1 \mathrm{mg} / \mathrm{mL})$, or appropriate amounts of immobilized hCA II, in a $1 \mathrm{~cm}$ spectrophotometric cell containing $1.8 \mathrm{~mL}$ of potassium phosphate buffer (0.1 M, pH 7.0) and $1 \mathrm{~mL}$ of $3 \mathrm{mM}$ p-NPA. For the free enzyme, the change in absorbance at $410 \mathrm{~nm}$ at $25^{\circ} \mathrm{C}$ was recorded over the first $20 \mathrm{~min}$. In the case of immobilized hCA II, the reaction mixture was stirred using a magnetic stirrer, the solution was centrifuged and the absorbance of the supernatant at $410 \mathrm{~nm}$ at $25{ }^{\circ} \mathrm{C}$ was measured every 3 minutes for the first 30 minutes. The product concentrations were corrected for the autohydrolysis of p-NPA by conducting blank experiments. The specific

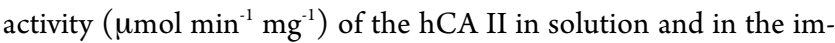
mobilized state were calculated from these corrected product concentrations. Specific activity is defined as the micromoles of substrate transformed per minute per milligram of the total protein sample.

\section{Solid-State NMR Experiments}

Solid-state NMR experiments were performed on a Bruker Avance III $400 \mathrm{MHz}$ spectrometer equipped with a widebore $9.4 \mathrm{~T}$ magnet, a Bruker Avance III $700 \mathrm{MHz}$ spectrometer with a widebore 16.4 T magnet, and a Bruker Avance III $850 \mathrm{MHz}$ spectrometer with a widebore $20 \mathrm{~T}$ magnet at room temperature. The powdered samples were packed into 1.0 and $3.2 \mathrm{~mm} \mathrm{ZrO}_{2}$ rotors and were spun at frequencies of 75 and $22 \mathrm{kHz}$ in 1.0 and $3.2 \mathrm{~mm}$ MAS probes, respectively. Chemical shifts were referenced externally relative to TMS for ${ }^{1} \mathrm{H}$ (adamantane: $1.87 \mathrm{ppm}$ ), ${ }^{13} \mathrm{C}$ (adamantane left peak: $38.4 \mathrm{ppm}$ ), ${ }^{15} \mathrm{~N}$ (glycine: $32.4 \mathrm{ppm}$ ) and ${ }^{29} \mathrm{Si}$ [octakis(trimethylsiloxy)silsesquioxane left peak: $12.1 \mathrm{ppm}]$. For insensitive nuclei $\left({ }^{13} \mathrm{C},{ }^{15} \mathrm{~N}\right.$ and $\left.{ }^{29} \mathrm{Si}\right)$, pulse sequences were employed with linearly ramped cross-polarization $(\mathrm{CP})^{43}$ and with small phase incremental alternation (SPINAL) ${ }^{44}{ }^{1} \mathrm{H}$ decoupling. All the NMR data were processed using TopSpin software. Further experimental and processing details can be found in the corresponding text and figure captions.

\section{RESULTS AND DISCUSSIONS}

Protein Expression, Purification and Enzymatic Assays

We successfully expressed four different double mutants of hCA II (S50C-C206S, S166C-C206S, S217C-C206S, S220C$\mathrm{C} 206 \mathrm{~S}$ ) in $\left[\mathrm{U}_{-}{ }^{15} \mathrm{~N}\right] / \mathrm{hCA}$ II as well as $\left[{ }^{15} \mathrm{~N}\right.$ Leu $] / \mathrm{hCA}$ II forms in good to excellent yields ( 60 to $200 \mathrm{mg} / \mathrm{L}$ culture). All protein constructs could be obtained in pure, homogeneous form as indicated by SDS-PAGE (Figure S1, Supporting Information). Only two bands were observed, one around $30 \mathrm{kDa}$ corresponding to hCA II and a second one at about $60 \mathrm{kDa}$ which proves that the cysteine residues are solvent-accessible and can form disulfide-linked hCA II dimers. A similar observation was made in the ESI-MS (Figure S2, Supporting Information). For freshly DDT reduced [U$\left.{ }^{15} \mathrm{~N}\right] /$ hCA II samples, only $\mathrm{m} / \mathrm{z}=29,449.7$ was obtained, in excellent agreement with the mass calculated $(\mathrm{m} / \mathrm{z}=29,448.7)$ for $\mathrm{C}_{1324} \mathrm{H}_{2018} \mathrm{~N}_{356} \mathrm{O}_{382} \mathrm{~S}_{3}$, corresponding to the loss of the $\mathrm{N}$-terminal methionine and a ${ }^{15} \mathrm{~N}$ enrichment of $98 \%$. On prolonged standing of the protein sample before MS analysis, $\mathrm{m} / \mathrm{z}=58,897.4$ was also found, corresponding again to a loss of two hydrogen atoms and the formation of a disulfide bond.

The enzymatic activities of the free and immobilized hCA II were assayed by measuring the hydrolysis of $\mathrm{p}-\mathrm{NPA}$ as substrate. A plot of the rate of product formation at increasing concentration of hCA II is shown in Figure S3. The measured specific activity of the immobilized enzyme $0.166 \mu \mathrm{mol} \mathrm{min}^{-1}$ (mg immobilized preparation $)^{-1}$ was converted to a value in terms of the protein present, 1.68 $\mu \mathrm{mol} \mathrm{min}^{-1}$ (mg protein $)^{-1}$ using the measured protein loading of $9.9 \mathrm{mg}$ protein per $100 \mathrm{mg}$ support. The converted value was then compared with the measured value for the free enzyme $2.3 \mu \mathrm{mol}$ $\min ^{-1}$ (mg protein $)^{-1}$ to show $71 \%$ retention of activity.

\section{Solid-State NMR Experiments}

Figure 1 shows the single $90^{\circ}$ pulse ${ }^{1} \mathrm{H}$ MAS NMR spectra of bare silica (Figure 1a), epoxy-silica (Figure 1b), $\left[{ }^{15} \mathrm{~N} \mathrm{Leu}\right] /$ hCA II (Figure 1c), $\left[\mathrm{U}^{15}{ }^{15} \mathrm{~N} / \mathrm{hCA}\right.$ II (Figure $1 \mathrm{~d}$ ), $\left[{ }^{15} \mathrm{~N}\right.$ Leu $] / \mathrm{hCA}$ II immobilized on epoxy-silica (Figure 1e) and $\left[\mathrm{U}-{ }^{15} \mathrm{~N}\right] / \mathrm{hCA}$ II immobilized on epoxy-silica (Figure 1f), all recorded at $75 \mathrm{kHz}$ MAS on a $\mathrm{B}_{0}=20 \mathrm{~T}$ magnet.

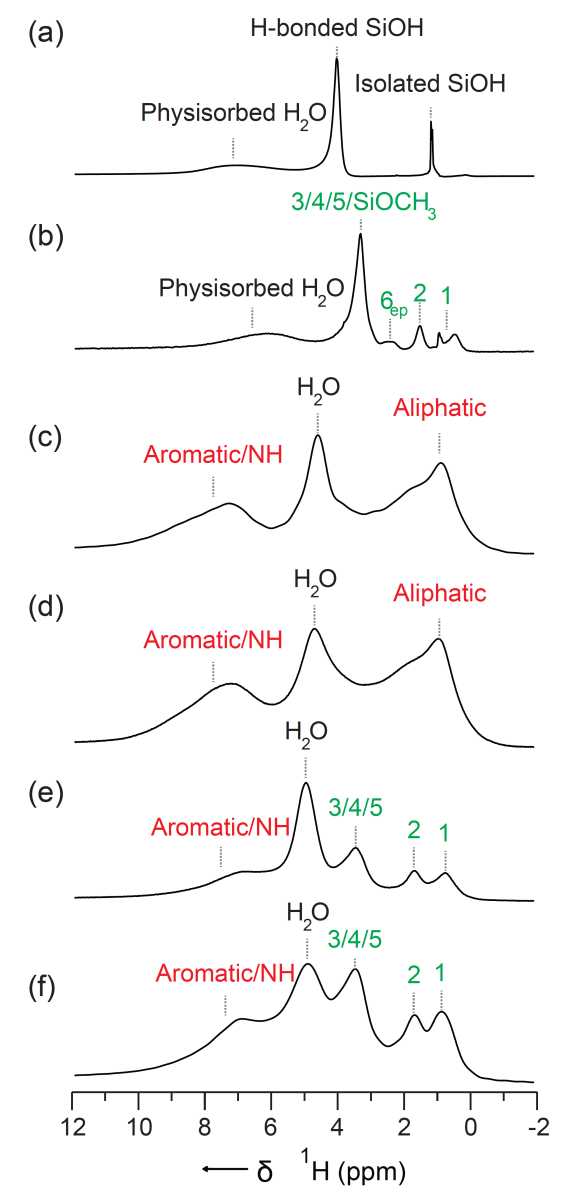

Figure 1. Single $90^{\circ}$ pulse ${ }^{1} \mathrm{H}$ MAS $(75 \mathrm{kHz})$ NMR spectra of (a) bare silica, (b) epoxy-silica, (c) $\left[{ }^{15} \mathrm{~N} \mathrm{Leu}\right] / \mathrm{hCA}$ II, (d) [U$\left.{ }^{15} \mathrm{~N}\right] / \mathrm{hCA}$ II, (e) $\left[{ }^{15} \mathrm{~N} \mathrm{Leu}\right] / \mathrm{hCA}$ II immobilized on epoxy-silica and (f) $\left[\mathrm{U}-{ }^{15} \mathrm{~N}\right] / \mathrm{hCA}$ II immobilized on epoxy-silica recorded on a $\mathrm{B}_{0}=20 \mathrm{~T}$ magnet. The spectra were acquired using 128 transients using a recycle interval of $2 \mathrm{~s}$. All spectra were processed without using window functions. The chemical shift assignments are based on the numbering scheme shown in Figure 3c.

The ${ }^{1} \mathrm{H}$ MAS NMR spectrum of bare silica (Figure 1a) is characterized by the signals appearing from the isolated silanol 
groups (between 1 to $2 \mathrm{ppm}$ ), hydrogen-bonded silanol groups (4 $\mathrm{ppm}$ ) and the broad peak ( 5 to $9 \mathrm{ppm}$ ) from the water molecules physically adsorbed onto the surface silanol groups. ${ }^{45}$ The spectrum of epoxy-silica (Figure $1 \mathrm{~b}$ ) is characterized by peaks appearing from $\mathrm{H} 1$ (0.8 ppm), $\mathrm{H} 2$ (1.5 ppm), H3, H4, H5, $\mathrm{SiOCH}_{3}(3.3 \mathrm{ppm})$ and $\mathrm{H}_{\text {epo }}(2.5 \mathrm{ppm})$ groups and is in good agreement with similar previous reports. ${ }^{30}$

The numbering scheme for the protons and the carbons from the epoxy-silica (green labels) and from the immobilized hCA II (red labels) is shown in Figure 3c. As in the spectrum of bare silica, the spectrum of epoxy-silica (Figure $1 \mathrm{~b}$ ) is also characterized by a broad peak spanning from 5.0 to $9.0 \mathrm{ppm}$ arising from the hydrogen-bonded water on the surface of the epoxy-silica. The width of the water peak can be ascribed to a lack of dynamics and the inhomogeneous broadening associated with a wide range of chemical shifts contributed by the different modes of hydrogen bonding with the surface silanol groups. ${ }^{46}$ The ${ }^{1} \mathrm{H}$ NMR spectra of the $\left[{ }^{15} \mathrm{~N}\right.$ Leu $] /$ hCA II (Figure 1c) and $\left[\mathrm{U}-{ }^{15} \mathrm{~N}\right] / \mathrm{hCA}$ II (Figure 1d) are almost identical and reveal mainly the signals from the aliphatic $(0$ to $3 \mathrm{ppm})$, water $(4.7 \mathrm{ppm})$, and the aromatic and amino groups (6 to $10 \mathrm{ppm})$. On the other hand, the spectra of the immobilized $\left[{ }^{15} \mathrm{~N}\right.$ Leu]/hCA II (Figure 1e) and $\left[\mathrm{U}-{ }^{15} \mathrm{~N}\right] / \mathrm{hCA}$ II (Figure 1f) are characterized by the signals appearing from the epoxy-silica ( 0 to $4.0 \mathrm{ppm})$, water $(4.7 \mathrm{ppm})$ in addition to the signals (6.0 to 10 $\mathrm{ppm})$ from the aromatic and amino groups from the immobilized enzyme. When compared to the spectrum of the epoxy-silica (Figure $1 \mathrm{~b}$ ), the spectra of the immobilized hCA II are characterized by the absence of the signals from the $\mathrm{C}_{\text {ep }}$ groups $(2.2 \mathrm{ppm})$, possibly indicating the epoxy-ring opening reaction during the process of immobilization under aqueous conditions.

Further confirmation of the chemical shift assignments from the epoxy-silica before and after immobilization were made by recording ${ }^{13} \mathrm{C}$ CPMAS experiments. Figure 2 shows the ${ }^{13} \mathrm{C}$ CPMAS spectra of epoxy-silica (Figure $2 \mathrm{a}$ ) and $\left[{ }^{15} \mathrm{~N} \mathrm{Leu}\right] / \mathrm{hCA}$ II immobilized on epoxy-silica (Figure 2b). The spectrum of epoxysilica (Figure 2a) is characterized by the peaks appearing from $\mathrm{C} 1$ (8.5 ppm), C2 (23.1 ppm), C3 (74.2 ppm), C4 (72.2 ppm), C5 $5_{\text {ep }}$ $(51.1 \mathrm{ppm}), \mathrm{C6}_{\text {ep }}(44.3 \mathrm{ppm})$ and $-\mathrm{SiOCH}_{3}(49.4 \mathrm{ppm})$ groups and is in good agreement with previous reports on a similar epoxysilica. ${ }^{30}$ The spectrum of $\left[{ }^{15} \mathrm{~N} \mathrm{Leu}\right] / \mathrm{hCA}$ II immobilized on epoxysilica (Figure 2b) is characterized by the ${ }^{13} \mathrm{C}$ signals from the aromatic (110 to $150 \mathrm{ppm}$ ), arginine side chain (zeta-carbon of the guanidine group; $160 \mathrm{ppm}$ ) and the carbonyl groups (175 ppm) from the protein, in addition to the signals from the modified epoxy-silica. Two distinct low ${ }^{13} \mathrm{C}$ frequency shoulder peaks from the Ile side chains ( $\mathrm{C}_{8}$ : between 15 to $20 \mathrm{ppm}$ ) could be also identified, in addition to the signals from the aliphatic region (between 20 to $40 \mathrm{ppm}$ ) from the immobilized hCA II. Furthermore, it is worth noting the relative decrease in the intensities of the peaks from the $\mathrm{C} 5_{\mathrm{ep}}(51.1 \mathrm{ppm})$ and $\mathrm{C} 6_{\mathrm{ep}}(44.3 \mathrm{ppm})$ groups and the appearance of new $\mathrm{C6}_{\mathrm{op}}(63.4 \mathrm{ppm})$ and $\mathrm{C6}_{\text {ie }}(40.4 \mathrm{ppm})$ peaks compared to the peaks associated with the remainder of the carbon atoms $(\mathrm{C} 1, \mathrm{C} 2, \mathrm{C} 3, \mathrm{C} 4)$.

To further confirm the chemical shift assignments from the epoxy-silica and the immobilized hCA II on epoxy-silica, twodimensional ${ }^{1} \mathrm{H}^{-13} \mathrm{C}$ HETCOR (HETero-nuclear CORrelation) spectra were recorded. Cross-polarization relies on dipolar couplings and, as a result, the cross-peaks in the two-dimensional ${ }^{1} \mathrm{H}$ ${ }^{13} \mathrm{C}$ FSLG-HETCOR spectra appear from strongly dipolar-coupled nuclear spins and so can provide information about the spatial pro-
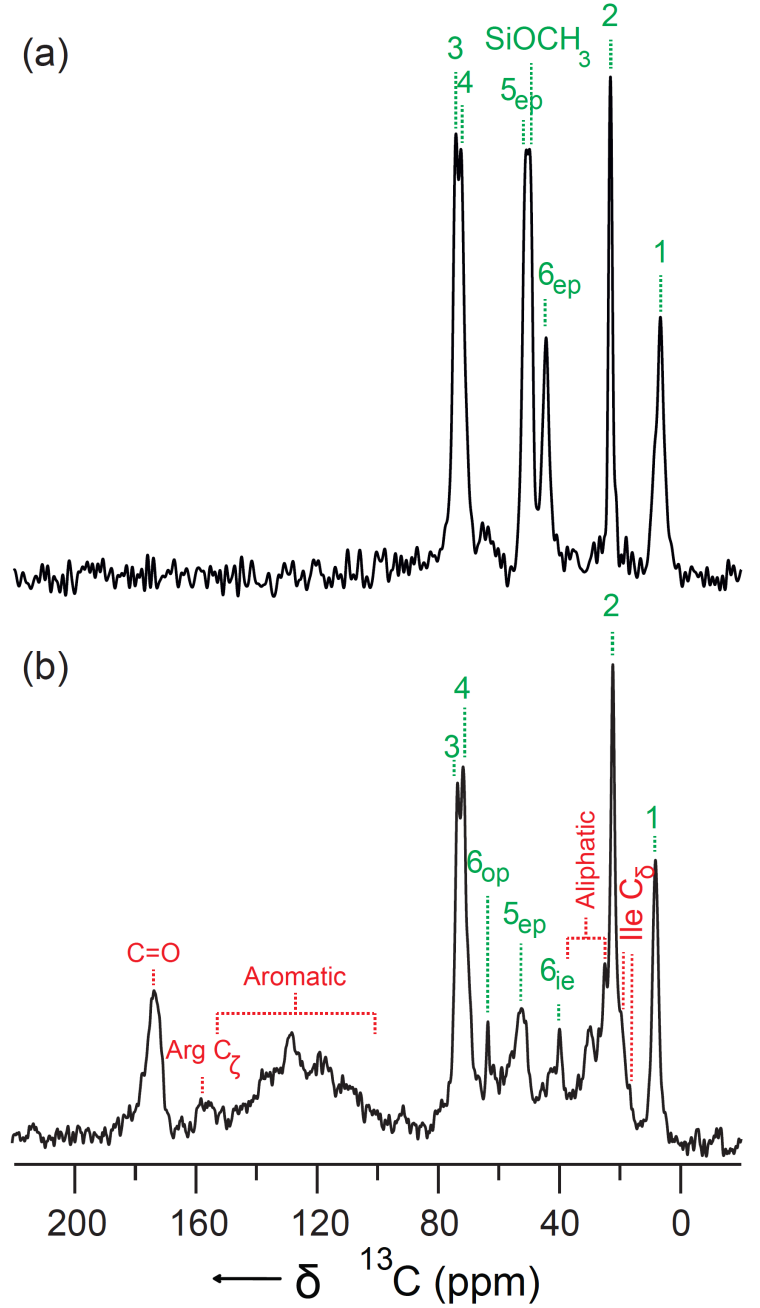

Figure $2 .{ }^{13} \mathrm{C}$ CPMAS spectra of (a) epoxy-silica and (b) $\left[{ }^{15} \mathrm{~N}\right.$ Leu]/hCA II immobilized on epoxy-silica in natural abundance. Both the spectra were acquired using a ${ }^{1} \mathrm{H}^{13} \mathrm{C} \mathrm{CP}$ contact time of 2 $\mathrm{ms}$ on a $\mathrm{B}_{0}=16.4 \mathrm{~T}$ spectrometer at a MAS frequency of $22 \mathrm{kHz}$. The spectrum (a) was acquired using 10240 transients and spectrum (b) was acquired using 409600 transients using a recycle interval of $2 \mathrm{~s}$. The spectrum (a) was processed without window functions and the spectrum (b) was processed with $100 \mathrm{~Hz}$ of exponential line broadening. The chemical shift assignments are based on the numbering scheme shown in Figure 3c.

ximity of the atoms involved. The spectrum of the epoxy-silica is well resolved (Figure 3a) and is characterized by ${ }^{1} \mathrm{H}^{-13} \mathrm{C}$ cross-peaks appearing from $\mathrm{H} 1-\mathrm{C} 1$ (0.5-6.4/8.4 ppm), H2-C2 (1.5-23.0 ppm), H3-C3 (2.8-74.1 ppm), H4-C4 (2.8-72.2 ppm), H5-C5 (2.7-51.1 ppm), H6-C6 (2.2-44.3 ppm) and $\mathrm{SiOCH}_{3}$ groups (2.8-49.6 ppm) in agreement with the single $90^{\circ}$ pulse ${ }^{1} \mathrm{H}$ and ${ }^{13} \mathrm{C}$ CPMAS spectra. The presence of two $\mathrm{C} 1$ peaks in the spectrum of epoxy-silica can perhaps be attributed to the different bonding environments of the GLYMO with the surface silicon species, with the first C1 (6.4 ppm) peak assigned to the carbon atoms from the $T_{2}$ silica species and the second $\mathrm{C} 1(8.4 \mathrm{ppm})$ peak assigned to the carbon atoms from the $\mathrm{T}_{1}$ species. The spectrum is also characterized by crosspeaks appearing from weakly dipolar-coupled ${ }^{1} \mathrm{H}-{ }^{13} \mathrm{C}$ spin pairs including $\mathrm{H} 1-\mathrm{C} 2$ (0.5-23.0 ppm), H3-C2 (2.8-23.0 ppm), H2-C3 (1.5-74.1 ppm) and $\mathrm{H} 2-\mathrm{C} 4$ (1.5-72.2 ppm). Furthermore, crosspeaks between the bulk ${ }^{1} \mathrm{H}$ water signals (4.3 ppm) with $\mathrm{C} 2, \mathrm{C} 3$, 
(a)

(b)
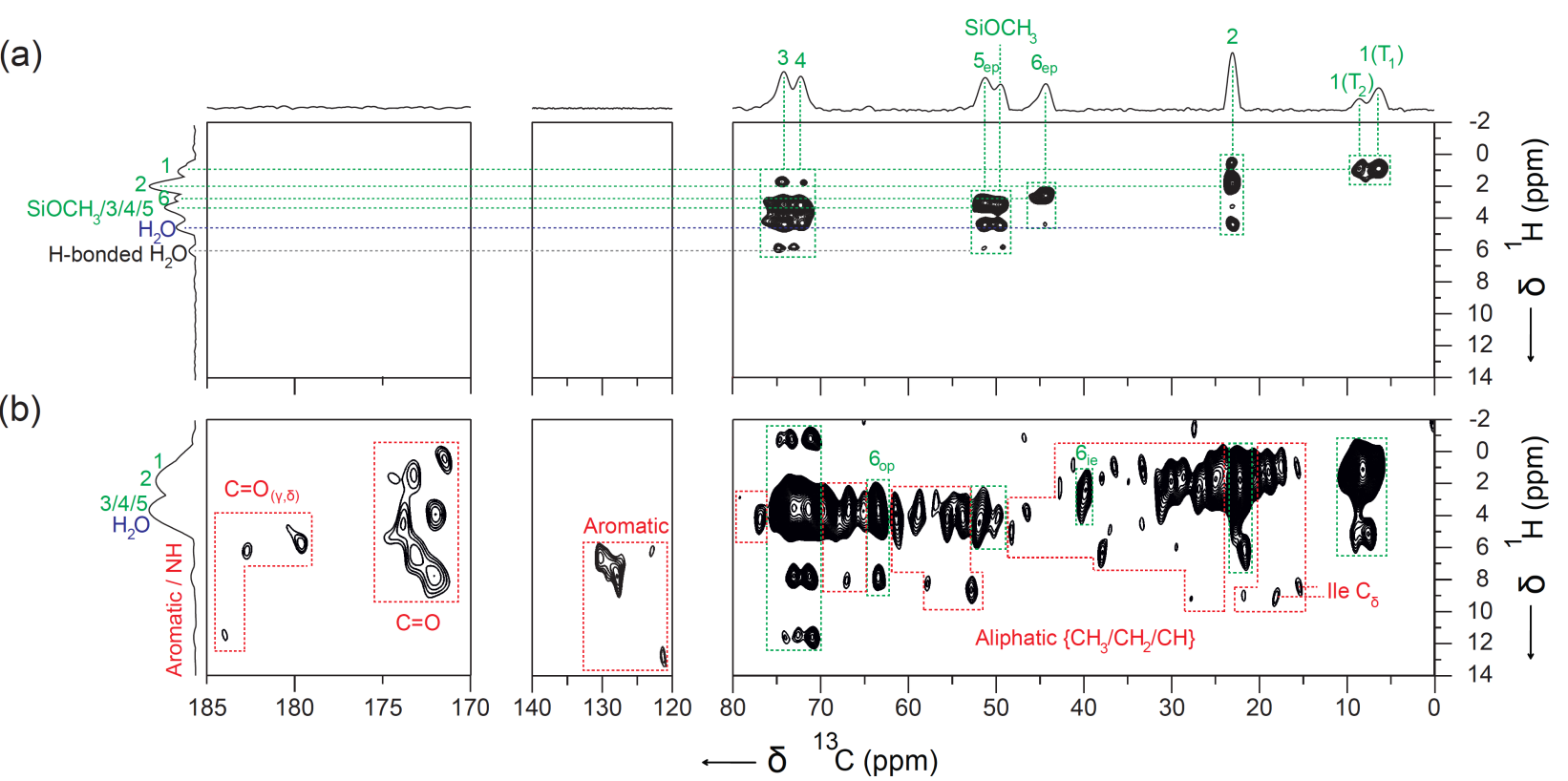

(c)

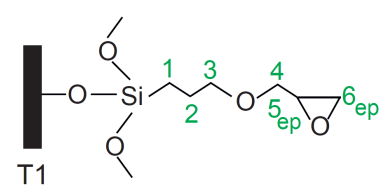

ep: epoxy-ring

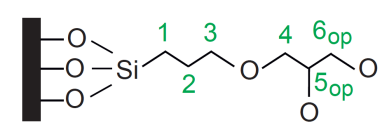

T3

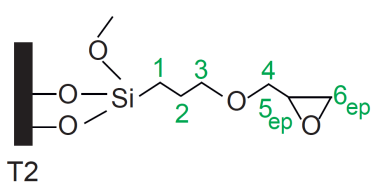

op: open epoxy-ring

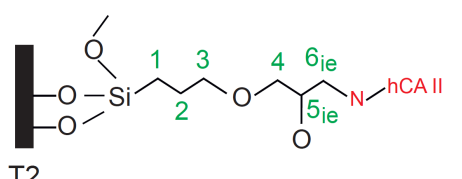

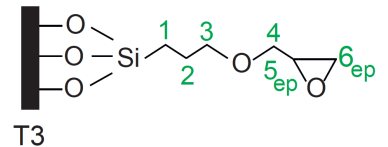

ie: immobilized enzyme

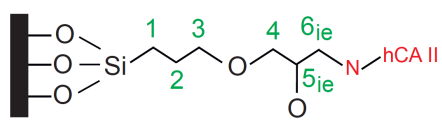

T3

Figure 3. Two-dimensional ${ }^{1} \mathrm{H}-{ }^{13} \mathrm{C}$ FSLG-HETCOR spectra of (a) epoxy-silica, (b) $\left[{ }^{15} \mathrm{~N}\right.$ Leu $] / \mathrm{hCA}$ II immobilized on epoxy-silica in natural abundance and (c) simplified schematic representation of epoxy-silica surface before (top row) and after (bottom row) covalent immobilization with hCA II. Both spectra were acquired using homonuclear FSLG decoupling and a ${ }^{1} \mathrm{H}^{-13} \mathrm{C} C \mathrm{C}$ contact time of $2 \mathrm{~ms}$ on a $\mathrm{B}_{0}=16.4 \mathrm{~T}$ spectrometer at a MAS frequency of $22 \mathrm{kHz}$. Spectrum (a) was acquired using 1024 transients for each of the 128 increments and spectrum (b) using 4096 transients for each of the 28 increments. High-power homo- and heteronuclear proton decoupling $(\sim 90 \mathrm{kHz})$ was applied during the FSLG $\tau$ intervals and also during ${ }^{13} \mathrm{C}$ acquisition. Spectrum (a) was processed without window functions and spectrum (b) using $50 \mathrm{~Hz}$ of line broadening in the direct (F2) dimension, with no line broadening in the indirect (F1) dimension. Chemical shift assignments from epoxy-silica are shown by green labels, bulk water in blue labels, and from the fingerprint regions from the covalently immobilized hCA II using red labels.

$\mathrm{C} 4, \mathrm{C} 5, \mathrm{C} 6$ and $\mathrm{SiOCH}_{3}$ groups are also visible in the spectrum, in addition to the cross-peaks between the ${ }^{1} \mathrm{H}$ signals from the physisorbed water molecules $(5.5 \mathrm{ppm})$ and the $\mathrm{C} 3, \mathrm{C} 4, \mathrm{C} 5$ and $\mathrm{SiOCH}_{3}$ groups from the epoxy-silica. On the other hand, the spectrum of the $\left[{ }^{15} \mathrm{~N} \mathrm{Leu}\right] / \mathrm{hCA}$ II immobilized on epoxy-silica (Figure $3 \mathrm{~b}$ ) is characterized by ${ }^{1} \mathrm{H}^{13} \mathrm{C}$ cross-peaks appearing from the fingerprint regions of the immobilized enzyme (red labels) in addition to the signals from the epoxy-silica (green labels). Successful immobilization of the hCA II on epoxy-silica is evident from the ${ }^{1} \mathrm{H}^{13} \mathrm{C}$ cross-peaks appearing from the carbonyl and the aromatic groups in the protein in addition to the signals appearing from the epoxy-silica. The systematic absence of the $\mathrm{C}_{\mathrm{ep}}-\mathrm{H} 6_{\mathrm{ep}}$ cross-peak (44.3-2.2 ppm) from the epoxy ring and the appearance of a new $\mathrm{C} 6_{\mathrm{op}}-\mathrm{H} 6_{\mathrm{op}}$ cross-peak (63.4-3.7 ppm) indicates the hydrolysis of the epoxy ring during the enzyme immobilization under aqueous conditions. In similar previous work on chymotrypsin immobilized on epoxy-silica, ${ }^{30}$ even though it was possible to observe and assign ${ }^{13} \mathrm{C}$ signals from the epoxy-silica and modified epoxy-silica, no distinct signals could be observed or assigned from the fingerprint regions from the immobilized enzyme. This is a consequence of the fact that natural abundance ${ }^{13} \mathrm{C}$ CPMAS NMR of covalently immobilized enzymes on epoxysilica can be extremely challenging due to the small amount of protein grafted onto the epoxy-silica surface. Furthermore, obtaining site-specific resonance assignments in natural abundance is additionally challenging due to the intense background signals arising from the epoxy-linker. Although the protein signals in the aliphatic region from the immobilized enzyme are masked by the intense background signals from the epoxy-silica, in this work chemical shift assignments from the immobilized hCA II can be made by directly comparing the chemical shifts from the epoxysilica before immobilization. It is worth noting the overall distribution and dispersion of chemical shifts from the fingerprint regions of the immobilized enzyme, in particular the distribution of 
the low ${ }^{13} \mathrm{C}$ frequency signals from the Ile side chains $\left(\mathrm{C}_{\delta}\right.$ : between 15 to $20 \mathrm{ppm}$ ) and the high frequency signals from the $\mathrm{Glu} / \mathrm{Gln}$ side chains $\left(\mathrm{C}_{(\gamma / \delta)}\right.$ : between 177 to $\left.185 \mathrm{ppm}\right)$. The spectrum in Figure $3 \mathrm{a}$ is also characterized by the reduced intensity of the $-\mathrm{SiOCH}_{3}$ (49.5-2.8 ppm) cross-peak, indicating extensive cross-linking of the silanol groups on the silica surface. This is in agreement with similar studies, where it has been reported that the silanol groups do not condense extensively during the initial silica surface modification but require the prolonged aqueous incubation during immobilization of the enzyme. ${ }^{30}$ This observation is also supported by the ${ }^{29} \mathrm{Si}$ CPMAS spectrum (Figure S4, Supporting information) of the immobilized enzyme, as this is mainly dominated by signals from the $T_{2}(-56 \mathrm{ppm})$ and $\mathrm{T}_{3}$ silicon species $(-66 \mathrm{ppm})$ in comparison with the spectrum of the epoxy-silica, which is mainly dominated by signals from the $T_{1}$ ($48 \mathrm{ppm})$ and $\mathrm{T}_{2}(-56 \mathrm{ppm})$ silicon species. Upon covalent binding of the enzyme, the $\mathrm{C} 6$ carbon atom of the epoxy ring $\mathrm{C}_{\mathrm{ep}}$ (44.3-2.2 ppm) is shifted to low ${ }^{13} \mathrm{C}$ frequency, labelled as $\mathrm{C}^{\mathrm{ie}}$ (40.1-4.2 ppm) (Figure 3b). Based on the chemical shift assignments, a simplified schematic representation of epoxy-silica surface before and after immobilization could be proposed (Figure $3 c)$.

\section{Structural Changes of Bulk and Surface Silica Species}

The changes in the silica bonding environments during different stages of enzyme immobilization were monitored by comparing ${ }^{29} \mathrm{Si}$ CPMAS NMR spectra from the bare silica, epoxy-silica and the hCA II immobilized on epoxy-silica (Figure S4, Supporting Information). The ${ }^{29} \mathrm{Si}$ CPMAS NMR spectrum of the bare silica (Figure S4a, Supporting Information) reveals mainly three different types of silicon species, $Q_{2}(-90 \mathrm{ppm}), \mathrm{Q}_{3}(-100 \mathrm{ppm})$ and $\mathrm{Q}_{4}(-110 \mathrm{ppm})$ in agreement with previous reports. ${ }^{47}$ The spectrum of epoxy-silica (Figure S4b, Supporting Information) shows new $\mathrm{T}_{1}(-48 \mathrm{ppm})$ and $\mathrm{T}_{2}(-56 \mathrm{ppm})$ species from the epoxy-silica in addition to the peaks from $\mathrm{Q}_{2}, \mathrm{Q}_{3}$ and $\mathrm{Q}_{4}$ species and is also in good agreement with previous reports. ${ }^{48}$ The appearance of new $T_{1}$ and $T_{2}$ groups and the reduced intensity of the $Q_{2}$ and $Q_{3}$ peaks confirms that GLYMO is covalently grafted on the silica surface and not chemically or physically adsorbed. The spectrum of epoxy-silica is mainly dominated by $T_{1}$ and $T_{2}$ species indicating the absence of extensive cross-condensation of silanol groups on the silica surface as evident from the absence of signals from the $\mathrm{T}_{3}$ species ( $\left.-66 \mathrm{ppm}\right)$. However, the ${ }^{29} \mathrm{Si}$ CPMAS NMR spectrum of hCA II immobilized on epoxy-silica (Figure S4c, Supporting Information) shows mainly $T_{2}$ and $T_{3}$ species and is characterized by the systematic absence of $T_{1}$ species.

Native Fold of the Protein before and after Immobilization

Structural changes in the enzyme before and after immobilization were monitored by comparing ${ }^{15} \mathrm{~N}$ CPMAS NMR and two-dimensional ${ }^{1} \mathrm{H}^{-15} \mathrm{~N}$ NMR FSLG-HETCOR spectra of [U$\left.{ }^{15} \mathrm{~N}\right] / \mathrm{hCA}$ II and $\left[{ }^{15} \mathrm{~N}\right.$ Leu $] / \mathrm{hCA}$ II samples. The ${ }^{15} \mathrm{~N}$ NMR spectra of the lyophilized hCA II (black) and immobilized hCA II (red) are almost identical (Figure S5, Supporting information). The spectra of $\left[\mathrm{U}_{-}{ }^{15} \mathrm{~N}\right] /$ hCA II before and after immobilization (Figure S5a, Supporting information) consist of ${ }^{15} \mathrm{~N}$ peaks arising from the backbone amide (NH: $100-140 \mathrm{ppm}$ ), lysine side chain $\left(\mathrm{N}_{\zeta} \sim 33 \mathrm{ppm}\right)$, arginine side chains $\left(\mathrm{N}_{\eta} \sim 73 \mathrm{ppm}, \mathrm{N}_{\varepsilon} \sim 85.0 \mathrm{ppm}\right)$ and the histidine side chains $\left(\mathrm{N}_{\delta 1}, \mathrm{~N}_{\varepsilon 2}: 155-185 \mathrm{ppm}\right)$. On the other hand, the spectra of $\left[{ }^{15} \mathrm{~N}\right.$ Leu $] /$ hCA II (Figure S5b, Supporting information) are characterized only by the backbone ami-
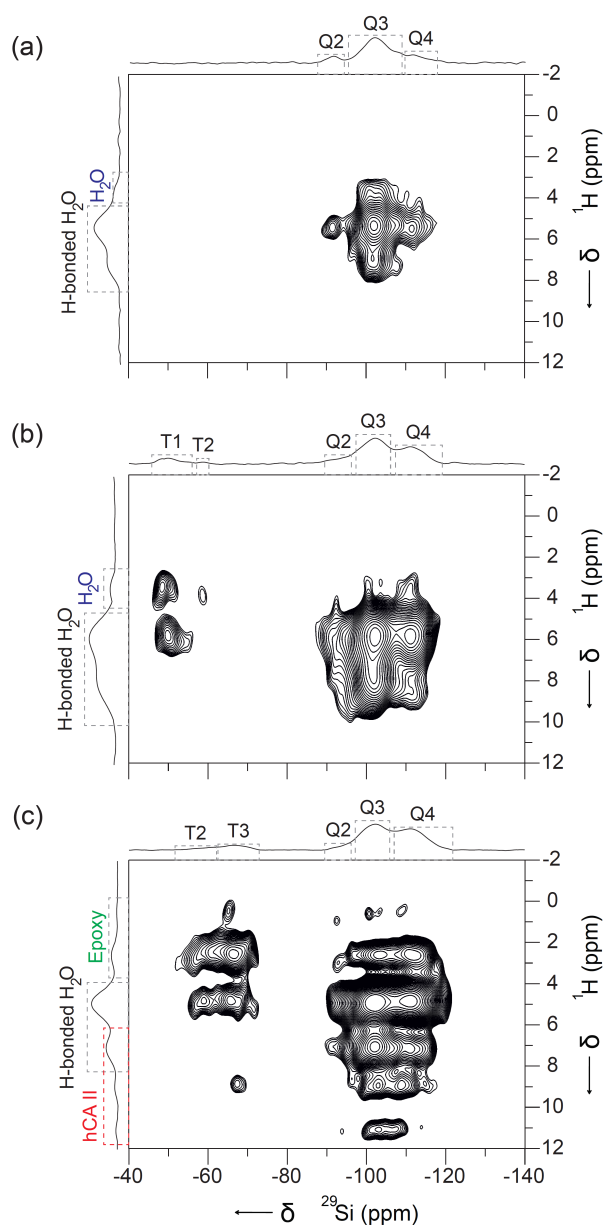

Figure 4. Two-dimensional ${ }^{1} \mathrm{H}^{-29} \mathrm{Si}$ FSLG-HETCOR spectra of (a) silica (b) epoxy-silica and (c) $\left[\mathrm{U}_{-}{ }^{15} \mathrm{~N}\right] / \mathrm{hCA}$ II immobilized on epoxy-silica acquired using homonuclear FSLG decoupling scheme and a ${ }^{1} \mathrm{H}^{-29} \mathrm{Si} \mathrm{CP}$ contact time of $10 \mathrm{~ms}$ on a $\mathrm{B}_{0}=9.4 \mathrm{~T}$ spectrometer at a MAS frequency of $22 \mathrm{kHz}$. All the spectra were acquired using 2048 transients for each of (a) 74 (b) 62 and (c) 70 increments and a recycle interval of $2 \mathrm{~s}$. High-power homoand heteronuclear proton decoupling $(\sim 90 \mathrm{kHz})$ was applied during the FSLG $\tau$ intervals and also during ${ }^{29} \mathrm{Si}$ acquisition. All spectra were processed using $100 \mathrm{~Hz}$ of line broadening in the direct dimension (F2) and no line broadening in the indirect (F1) dimension. Chemical shift assignments from epoxy-silica are shown by green labels, water in blue labels, and from the fingerprint regions of the immobilized enzyme using red labels.

de peaks (NH: 100-140 ppm) and the systematic absence of the side chain ${ }^{15} \mathrm{~N}$ signals from lysine, arginine and histidine residues, indicating the successful selective isotopic enrichment of leucine residues and the absence of any isotopic scrambling. It is worth noting that no significant chemical shift perturbations or line broadening could be observed from the backbone amide peaks (NH: 100-140 ppm) before and after immobilization for both $\left[\mathrm{U}-{ }^{15} \mathrm{~N}\right] / \mathrm{hCA}$ II and $\left[{ }^{15} \mathrm{~N} \mathrm{Leu}\right] / \mathrm{hCA}$ II samples. Although the epoxy groups can react with different reactive amino acid residues from the protein, the preferential distribution of the exposed side chain amino groups from the lysine residues in solution $\left(\mathrm{N}_{\varepsilon}\right)$ makes them favorable for reaction with the epoxy groups. ${ }^{49}$

To obtain further structural details from the enzyme before and after immobilization, two-dimensional ${ }^{1} \mathrm{H}_{-}{ }^{15} \mathrm{~N}$ FSLG- 
HETCOR spectra were recorded. The spectra (Figure 5a) of [U$\left.{ }^{15} \mathrm{~N}\right] / \mathrm{hCA}$ II before (black) and after (red) immobilization are al-
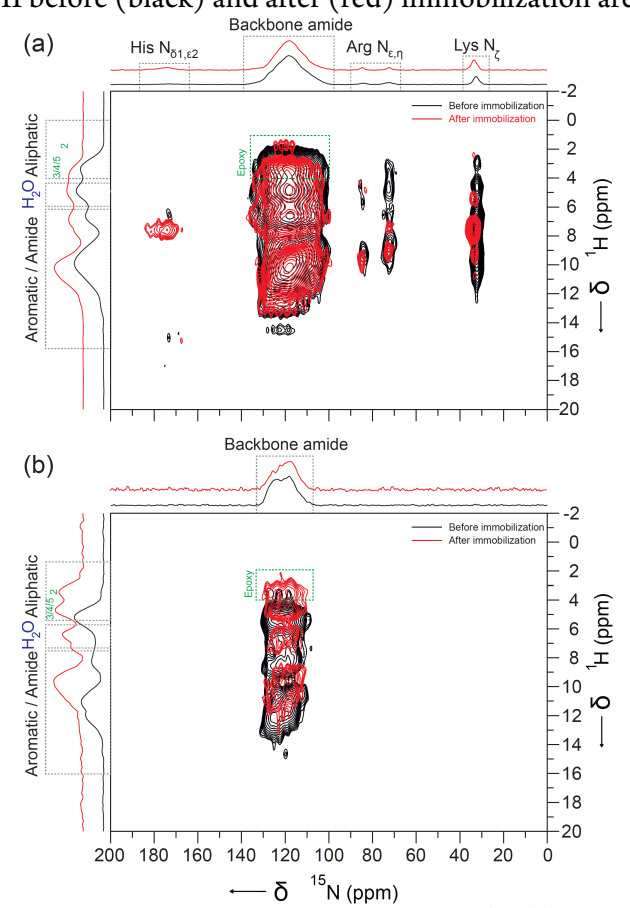

Figure 5. Overlay of the two-dimensional ${ }^{1} \mathrm{H}^{-15} \mathrm{~N}$ FSLGHETCOR spectra of (a) $\left[\mathrm{U}_{-}{ }^{15} \mathrm{~N}\right] / \mathrm{hCA}$ II before (black) and after (red) immobilization on epoxy-silica, (b) Overlay of the two-dimensional ${ }^{1} \mathrm{H}^{-15} \mathrm{~N}$ FSLG-HETCOR spectra of $\left[{ }^{15} \mathrm{~N}\right.$ Leu]/hCA II before (black) and after (red) immobilization on epoxy-silica. All spectra were acquired using homonuclear FSLG decoupling and a ${ }^{1} \mathrm{H}-{ }^{15} \mathrm{~N}$ CP contact time of $2 \mathrm{~ms}$ on a $\mathrm{B}_{0}=16.4$ $\mathrm{T}$ spectrometer at a MAS frequency of $22 \mathrm{kHz}$. The spectrum of $\left[\mathrm{U}-{ }^{15} \mathrm{~N}\right] / \mathrm{hCA}$ II before immobilization on epoxy-silica was acquired using 512 transients and after immobilization using 1024 transients for each of the 100 increments. The spectrum of $\left[{ }^{15} \mathrm{~N}\right.$ Leu]/hCA II before immobilization on epoxy-silica was acquired using 512 transients and after immobilization using 2048 transients for each of the 100 increments. High-power homo- and heteronuclear proton decoupling $(\sim 90 \mathrm{kHz})$ was applied during the FSLG $\tau$ intervals and also during ${ }^{15} \mathrm{~N}$ acquisition. All spectra were processed using $50 \mathrm{~Hz}$ of line broadening in the direct dimension (F2) and with no window function in the indirect dimension (F1). Chemical shift assignments from the epoxy-silica are shown by green labels and from the water in blue labels. The chemical shift assignments from the epoxy-silica are based on the numbering scheme shown in Figure 3c.

most identical. The spectra reveal short (one bond) and longrange (more than two bonds) ${ }^{1} \mathrm{H}-{ }^{15} \mathrm{~N}$ cross-peaks between the protons from the aliphatic (1.5-4.0 ppm), bulk water (4.8 ppm), and backbone amide/aromatic groups $(6.0-10.0 \mathrm{ppm})$ with the nitrogen atoms from the lysine side chain $\left(\mathrm{N}_{\zeta} \sim 33.0 \mathrm{ppm}\right)$, arginine side chains $\left(\mathrm{N}_{\eta} \sim 73 \mathrm{ppm}, \mathrm{N}_{\varepsilon} \sim 85.0 \mathrm{ppm}\right)$, backbone amide (NH: $100-140$ ppm) and histidine side chains $\left(\mathrm{N}_{\delta 1}, \mathrm{~N}_{\varepsilon 2} \sim 174.0\right.$ ppm). The highly deshielded protons (10-16 ppm) correlated with the backbone amide (116-130 ppm) and the histidine side chain $\left(\mathrm{N}_{\delta 1}, \mathrm{~N}_{\varepsilon 2} \sim 174.0 \mathrm{ppm}\right)$ can be ascribed to the imidazole $\mathrm{N}-\mathrm{H}$ protons from the histidine residues at the active site. The spectrum of $\left[\mathrm{U}_{-}{ }^{15} \mathrm{~N}\right] / \mathrm{hCA}$ II in the immobilized state is also characterized by the ${ }^{1} \mathrm{H}^{-15} \mathrm{~N}$ cross-peaks (green labels) between the protons from the epoxy-silica $(\sim 1.6 \mathrm{ppm})$ and the backbone amide $(\sim 120 \mathrm{ppm})$ groups indicating their close proximity $(<10 \AA)$ in space. The spectra (Figure $5 b$ ) of the $\left[{ }^{15} \mathrm{~N} \mathrm{Leu}\right] / \mathrm{hCA}$ II before (black) and after (red) immobilization are similarly also almost identical. Both spectra are characterized by ${ }^{1} \mathrm{H}_{-}{ }^{15} \mathrm{~N}$ cross-peaks between the backbone amide (NH: $100-140 \mathrm{ppm})$ and the protons from the aliphatic (2.0-4.0 ppm), bulk water (4.8 ppm), and backbone amide/aromatic groups (6-14 ppm). The overall distribution of chemical shifts from the protein before and after immobilization indicates that the structural integrity of the enzyme is not significantly altered upon covalent immobilization and is comparable to that of the lyophilized state. This result can be compared with the observation that the immobilized hCA II retained $71 \%$ of its enzymatic activity when compared to the free enzyme in solution.

It should be noted that lyophilized states of the proteins are not necessarily identical to the native structures in solution and available reports on lyophilized powders of proteins are controversial. Although some studies ${ }^{50-54}$ indicate significant reversible conformational change upon lyophilisation, others ${ }^{55-58}$ show that the lyophilized state is comparable and identical to that in solution. When compared to the crystalline state, the poor resolution from the lyophilized proteins observed by MAS NMR can be attributed to the introduction of conformational heterogeneity during the lyophilization process. Better insights about the native fold of the protein before and after immobilization might be obtained by comparing spectra (for example, ${ }^{1} \mathrm{H}$-detected twodimensional ${ }^{1} \mathrm{H}_{-}{ }^{15} \mathrm{~N}$ HSQC experiments under fast MAS) of the micro/nano crystalline protein and of the immobilized state. Such experiments are an active area of research in our laboratory but are beyond the scope of this current manuscript.

\section{CONCLUSIONS}

In summary, we have shown that solid-state MAS NMR can be successfully employed to yield detailed structural information from a covalently immobilized heterogeneous biocatalytic system. Obtaining site-specific information from covalently immobilized proteins on silica using NMR at natural isotopic abundance is challenging due to the limited experimental sensitivity arising from the small amount of protein grafted onto the surface of the silica support. Preparation of the hCA II samples in the [U$\left.{ }^{15} \mathrm{~N}\right] / \mathrm{hCA}$ II and $\left[{ }^{15} \mathrm{~N} \mathrm{Leu}\right] / \mathrm{hCA}$ II forms has enabled us to gain additional structural insights from the enzyme before and after immobilization. ${ }^{1} \mathrm{H}$ MAS NMR experiments at $75 \mathrm{kHz}$ spinning rate at high magnetic fields $\left(B_{0}=20 \mathrm{~T}\right)$ have aided in revealing the different ${ }^{1} \mathrm{H}$ environments from the epoxy-silica and the immobilized enzyme in the as-synthesized state. Confirmation of the chemical shift assignments from the epoxy-silica and the immobilized enzyme before and after immobilization were accomplished using one- and two-dimensional ${ }^{13} \mathrm{C}$ CPMAS NMR experiments. A comparison of the two-dimensional ${ }^{1} \mathrm{H}^{13}{ }^{13} \mathrm{C}$ FSLGHETCOR spectra of the epoxy-silica and immobilized enzyme reveals that $-\mathrm{SiOCH}_{3}$ groups do not cross-link extensively on the surface of the silica during the synthesis of epoxy-silica; this crosslinking requires prolonged aqueous incubation during the immobilization. This was further confirmed by ${ }^{29} \mathrm{Si}$ CPMAS NMR experiments where the spectrum of the epoxy-silica consists mainly of $T_{1}$ and $T_{2}$ species while the spectrum of the immobilized enzyme is mainly dominated by $\mathrm{T}_{2}$ and the $\mathrm{T}_{3}$ species. Most notably, comparison of the ${ }^{15} \mathrm{~N}$ CPMAS and two-dimensional ${ }^{1} \mathrm{H}-{ }^{15} \mathrm{~N}$ FSLG-HETCOR spectra before and after covalent immobilization reveals that the structural integrity of the protein is not dras- 
tically changed upon immobilization. This result can be compared with the observation that the immobilized enzyme system retained $71 \%$ of its effective specific activity when compared with the free hCA II in solution.

\section{ASSOCIATED CONTENT}

Supporting Information. SDS-PAGE of uniformly ${ }^{15} \mathrm{~N}$-labelled hCA II - S50C-C206S before and after subsequent purification steps. Deconvoluted ESI-MS spectra of uniformly ${ }^{15} \mathrm{~N}$-labelled hCA II S50C-C206S after TCEP reduction. Plot of the rate of product formation at increasing concentration of hCA II. One-dimensional ${ }^{29} \mathrm{Si}$ CPMAS spectra of silica, epoxy-silica and hCA II immobilized on epoxy-silica. One-dimensional ${ }^{15} \mathrm{~N}$ CPMAS NMR spectra of [U$\left.{ }^{15} \mathrm{~N}\right] / \mathrm{hCA}$ II and $\left[{ }^{15} \mathrm{~N} \mathrm{Leu}\right] / \mathrm{hCA}$ II before and after immobilization on epoxy-silica. This material is available free of charge via the Internet at http://pubs.acs.org.

\section{AUTHOR INFORMATION}

\section{Corresponding Authors}

*S. Varghese: e-mail, s.varghese@lancaster.ac.uk.

*S. Wimperis: e-mail, s.wimperis@lancaster.ac.uk.

Notes

The authors declare no competing financial interest.

\section{ACKNOWLEDGEMENT}

We thank the Leverhulme Trust (award RPG-2013-361) for financial support. We are indebted to Dr Kaspar Zimmermann for the preparation of all protein constructs, to Dr Elisa Nogueira for assistance, and the Swiss National Science Foundation for a grant to D.H. (SNF 200021_130263). The UK 850 MHz Solid-State NMR Facility used in this research was funded by EPSRC and BBSRC (contract reference PR140003), as well as the University of Warwick including via part funding through Birmingham Science City Advanced Materials Projects 1 and 2 supported by Advantage West Midlands (AWM) and the European Regional Development Fund (ERDF). Collaborative assistance from the $850 \mathrm{MHz}$ Facility Manager (Dr Dinu Iuga, University of Warwick) is gratefully acknowledged. We also thank Daiso Chemical Co. Ltd, Japan for donating the silica support used in this research.

\section{ABBREVIATIONS}

hCA II, human carbonic anhydrase II; MAS, magic-angle spinning; CP, cross-polarization; DNaseI, Deoxyribonuclease I; DTT, Dithiothreitol; E.coli, escherichia coli; ESI-MS, electrospray ionization mass spectrometry; HETCOR, hetero-nuclear correlation; ie, immobilized enzyme; IPTG, isopropyl $\beta$-D-1-thiogalactopyranoside; FSLG, frequency-switched Lee-Goldberg; SDS, sodium dodecyl sulfate; GLYMO, (3-glycidyloxypropyl)trimethoxysilane; EEW, epoxy equivalent weight; TMS, tetramethylsilane; PMSF, phenylmethylsulfonyl fluoride; SPINAL, small phase incremental alternation; TCEP, (tris(2-carboxyethyl)phosphine).

\section{REFERENCES}

1. Kuchler, A.; Yoshimoto, M.; Luginbuhl, S.; Mavelli, F.; Walde, P. Enzymatic Reactions in Confined Environments. Nat. Nanotechnol. 2016, 11, 409-420.

2. Datta, S.; Christena, L. R.; Rajaram, Y. R. S. Enzyme Immobilization: An Overview on Techniques and Support Materials. 3 Biotech. 2013, 3, 1-9.

3. Jothiramalingam, R.; Wang, M. K. Review of Recent Developments in Solid Acid, Base, and Enzyme Catalysts (Heterogeneous) for
Biodiesel Production Via Transesterification. Ind. Eng. Chem. Res. 2009, 48, 6162-6172.

4. Weetall, H. H. Enzymes Immobilized on Inorganic Supports. Trends Biotechnol. 1985, 3, 276-280.

5. Bolivar, J. M.; Eisl, I.; Nidetzky, B. Advanced Characterization of Immobilized Enzymes as Heterogeneous Biocatalysts. Catal. Today 2016, 259, Part 1, 66-80.

6. Ravera, E.; Martelli, T.; Geiger, Y.; Fragai, M.; Goobes, G.; Luchinat, C. Biosilica and Bioinspired Silica Studied by Solid-State NMR. Coord. Chem. Rev. 2016, 327-328, 110-122.

7. McDermott, A. Structure and Dynamics of Membrane Proteins by Magic Angle Spinning Solid-State NMR. Annu. Rev. Biophys. 2009, 38, 385-403.

8. Xue, P.; Xu, F.; Xu, L. Epoxy-Functionalized Mesostructured Cellular Foams as Effective Support for Covalent Immobilization of Penicillin G Acylase. Appl. Surf. Sci. 2008, 255, 1625-1630.

9. Hartono, S. B.; Qiao, S. Z.; Liu, J.; Jack, K.; Ladewig, B. P.; Hao, Z.; Lu, G. Q. M. Functionalized Mesoporous Silica with Very Large Pores for Cellulase Immobilization. J. Phys. Chem. C 2010, 114, 83538362.

10. Grünberg, B.; Emmler, T.; Gedat, E.; Shenderovich, I.; Findenegg, G. H.; Limbach, H.-H.; Buntkowsky, G. Hydrogen Bonding of Water Confined in Mesoporous Silica MCM-41 and SBA-15 Studied by ${ }^{1} \mathrm{H}$ Solid-State NMR. Chem. Eur. J. 2004, 10, 5689-5696.

11. Park, M.; Park, S. S.; Selvaraj, M.; Zhao, D.; Ha, C.-S. Hydrophobic Mesoporous Materials for Immobilization of Enzymes. Micropor. Mesopor. Mat. 2009, 124, 76-83.

12. Ramírez-Wong, D. G.; Coelho-Diogo, C.; Aimé, C.; Bonhomme, C.; Jonas, A. M.; Demoustier-Champagne, S. Effects of Geometrical Confinement in Membrane Pores on Enzyme-Based Layer-by-Layer Assemblies. Appl. Surf. Sci. 2015, 338, 154-162.

13. Reshmi, R.; Sugunan, S. Improved Biochemical Characteristics of Crosslinked $\beta$-Glucosidase on Nanoporous Silica Foams. J. Mol. Catal. B: Enzym. 2013, 85-86, 111-118.

14. Yiu, H. H. P.; Wright, P. A.; Botting, N. P. Enzyme Immobilisation Using SBA-15 Mesoporous Molecular Sieves with Functionalized Surfaces. J. Mol. Catal. B: Enzym. 2001, 15, 81-92.

15. Yadav, R.; Wanjari, S.; Prabhu, C.; Kumar, V.; Labhsetwar, N.; Satyanarayanan, T.; Kotwal, S.; Rayalu, S. Immobilized Carbonic Anhydrase for the Biomimetic Carbonation Reaction. Energy Fuels 2010, 24, 6198-6207.

16. Fei, X.; Chen, S.; Liu, D.; Huang, C.; Zhang, Y. Comparison of Amino and Epoxy Functionalized SBA-15 Used for Carbonic Anhydrase Immobilization. J. Biosci. Bioeng. 2016, 122, 314-321.

17. Pierre, A.; Buisson, P. Influence of the Porous Texture of Silica Gels on the Enzymatic Activity of Lipases in Esterification Reactions. J. Mol. Catal. B: Enzym. 2001, 11, 639-647.

18. Na, W.; Wei, Q.; Lan, J.-N.; Nie, Z.-R.; Sun, H.; Li, Q.-Y. Effective Immobilization of Enzyme in Glycidoxypropyl-Functionalized Periodic Mesoporous Organosilicas (Pmos). Micropor. Mesopor. Mat. $2010,134,72-78$.

19. Wang, C.-f.; Zhou, G.-w.; Li, Y.-J.; Lu, N.; Song, H.-b.; Zhang, L. Biocatalytic Esterification of Caprylic Acid with Caprylic Alcohol by Immobilized Lipase on Amino-Functionalized Mesoporous Silica. Colloids Surf., A 2012, 406, 75-83.

20. Roehrich, A.; Drobny, G. Solid-State NMR Studies of Biomineralization Peptides and Proteins. Acc. Chem. Res. 2013, 46, 21362144.

21. Shaw, W. J. Solid-State NMR Studies of Proteins Immobilized on Inorganic Surfaces. Solid State Nucl. Magn. Reson. 2015, 70, 1-14.

22. Goobes, G.; Stayton, P. S.; Drobny, G. P. Solid State NMR Studies of Molecular Recognition at Protein-Mineral Interfaces. Prog. Nucl. Magn. Reson. Spectrosc. 2007, 50, 71-85.

23. Goobes, G. Past and Future Solid-State NMR Spectroscopy Studies at the Convergence Point between Biology and Materials Research. Isr.J. Chem. 2014, 54, 113-124.

24. Reid, D. G.; Duer, M. J.; Murray, R. C.; Wise, E. R. The Organic-Mineral Interface in Teeth is Like That in Bone and Dominated by 
Polysaccharides: Universal Mediators of Normal Calcium Phosphate Biomineralization in Vertebrates? Chem. Mater. 2008, 20, 3549-3550.

25. Chow, W. Y.; Rajan, R.; Muller, K. H.; Reid, D. G.; Skepper, J. N.; Wong, W. C.; Brooks, R. A.; Green, M.; Bihan, D.; Farndale, R. W.; Slatter, D. A.; Shanahan, C. M.; Duer, M. J. NMR Spectroscopy of Native and in Vitro Tissues Implicates PolyADP Ribose in Biomineralization. Science 2014, 344, 742-746.

26. Fragai, M.; Luchinat, C.; Martelli, T.; Ravera, E.; Sagi, I.; Solomonov, I.; Udi, Y. SSNMR of Biosilica-Entrapped Enzymes Permits an Easy Assessment of Preservation of Native Conformation in Atomic Detail. Chem. Commun. 2014, 50, 421-423.

27. Martelli, T.; Ravera, E.; Louka, A.; Cerofolini, L.; Hafner, M.; Fragai, M.; Becker, C. F. W.; Luchinat, C. Atomic-Level Quality Assessment of Enzymes Encapsulated in Bioinspired Silica. Chem. Eur. J. 2016, $22,425-432$

28. Ravera, E.; Michaelis, V. K.; Ong, T.-C.; Keeler, E. G.; Martelli, T.; Fragai, M.; Griffin, R. G.; Luchinat, C. Biosilica-Entrapped Enzymes Studied by Using Dynamic Nuclear-Polarization-Enhanced HighField NMR Spectroscopy. ChemPhysChem 2015, 16, 2751-2754.

29. Ravera, E.; Cerofolini, L.; Martelli, T.; Louka, A.; Fragai, M.; Luchinat, C. ${ }^{1}$ H-Detected Solid-State NMR of Proteins Entrapped in Bioinspired Silica: A New Tool for Biomaterials Characterization. Sci. Rep.2016, 6, 27851.

30. Fauré, N. E.; Halling, P. J.; Wimperis, S. A Solid-State NMR Study of the Immobilization of $\alpha$-Chymotrypsin on Mesoporous Silica. J. Phys. Chem. C2014, 118, 1042-1048.

31. Eriksson, A. E.; Jones, T. A.; Liljas, A. Refined Structure of Human Carbonic Anhydrase II at 2.0 Å Resolution. Proteins: Struct., Funct., Bioinf. 1988, 4, 274-282.

32. Venters, R. A.; Farmer Ii, B. T.; Fierke, C. A.; Spicer, L. D. Characterizing the Use of Perdeuteration in NMR Studies of Large Proteins: ${ }^{13} \mathrm{C},{ }^{15} \mathrm{~N}$ and ${ }^{1} \mathrm{H}$ Assignments of Human Carbonic Anhydrase II. J. Mol. Biol. 1996, 264, 1101-1116.

33. Lipton, A. S.; Heck, R. W.; Ellis, P. D. Zinc Solid-State NMR Spectroscopy of Human Carbonic Anhydrase: Implications for the Enzymatic Mechanism. J. Am. Chem. Soc. 2004, 126, 4735-4739.

34. Jonasson, P.; Kjellsson, A.; Sethson, I.; Jonsson, B.-H. Denatured States of Human Carbonic Anhydrase II: An NMR Study of Hydrogen/Deuterium Exchange at Tryptophan-Indole- $\mathrm{H}_{\mathrm{N}}$ Sites. FEBS Lett. 1999, 445, 361-365.

35. Nair, S. K.; Calderone, T. L.; Christianson, D. W.; Fierke, C. A. Altering the Mouth of a Hydrophobic Pocket. Structure and Kinetics of Human Carbonic Anhydrase II Mutants at Residue Val-121. J. Biol. Chem. 1991, 266, 17320-17325.

36. Zheng, L.; Baumann, U.; Reymond, J.-L. An Efficient OneStep Site-Directed and Site-Saturation Mutagenesis Protocol. Nucleic Acids Res. 2004, 32, e115.

37. Herman, D. P.; Field, L. R.; Abbott, S. The Size-Exclusion Chromatographic Behavior of Synthetic Water-Soluble Polymers on Diol Bonded Phase Supports. J. Chromatogr. Sci. 1981, 19, 470-476.

38. Chen, S.; Sui, J.; Chen, L. Positional Assembly of Hybrid Polyurethane Nanocomposites Via Incorporation of Inorganic Building Blocks into Organic Polymer. Colloid. Polym. Sci. 2004, 283, 66-73.

39. Jay, R. R. Direct Titration of Epoxy Compounds and Aziridines. Anal. Chem. 1964, 36, 667-668.

40. Wheatley, J. B.; Schmidt, D. E. Salt-Induced Immobilization of Proteins on a High-Performance Liquid Chromatographic Epoxide Affinity Support. J. Chromatogr. A 1993, 644, 11-16.

41. Bradford, M. M. A Rapid and Sensitive Method for the Quantitation of Microgram Quantities of Protein Utilizing the Principle of Protein-Dye Binding. Anal. Biochem. 1976, 72, 248-254.

42. Armstrong, J. M.; Myers, D. V.; Verpoorte, J. A.; Edsall, J. T. Purification and Properties of Human Erythrocyte Carbonic Anhydrases. J. Biol. Chem. 1966, 241, 5137-5149.

43. Pines, A.; Gibby, M. G.; Waugh, J. S. Proton-Enhanced NMR of Dilute Spins in Solids. J. Chem. Phys 1973, 59, 569-590.
44. Fung, B. M.; Khitrin, A. K.; Ermolaev, K. An Improved Broadband Decoupling Sequence for Liquid Crystals and Solids. J. Magn. Reson. 2000, 142, 97-101.

45. Bronnimann, C. E.; Zeigler, R. C.; Maciel, G. E. Proton NMR Study of Dehydration of the Silica Gel Surface. J. Am. Chem. Soc. 1988, 110, 2023-2026.

46. Maciel, G. E. Probing Hydrogen Bonding and the Local Environment of Silanols on Silica Surfaces Via Nuclear Spin Cross Polarization Dynamics. J. Am. Chem. Soc. 1996, 118, 401-406.

47. Maciel, G. E.; Sindorf, D. W. Silicon-29 NMR Study of the Surface of Silica Gel by Cross Polarization and Magic-Angle Spinning. J. Am. Chem. Soc. 1980, 102, 7606-7607.

48. Bayer, E.; Albert, K.; Reiners, J.; Nieder, M.; Müller, D. Characterization of Chemically Modified Silica Gels by ${ }^{29} \mathrm{Si}$ and ${ }^{13} \mathrm{C}$ CrossPolarization and Magic Angle Spinning Nuclear Magnetic Resonance. J. Chromatogr. A 1983, 264, 197-213.

49. Hanefeld, U.; Gardossi, L.; Magner, E. Understanding Enzyme Immobilisation. Chem. Soc. Rev. 2009, 38, 453-468.

50. Desai, U. R.; Osterhout, J. J.; Klibanov, A. M. Protein Structure in the Lyophilized State: A Hydrogen Isotope Exchange/NMR Study with Bovine Pancreatic Trypsin Inhibitor. J. Am. Chem. Soc. 1994, 116, 9420-9422.

51. Poole, P. L.; Finney, J. L. Hydration-Induced Conformational and Flexibility Changes in Lysozyme at Low Water Content. Int. J. Biol. Macromol. 1983, 5, 308-310.

52. Yu, N.-T.; Jo, B. H.; O'Shea, D. C. Laser Raman Scattering of Cobramine B, a Basic Protein from Cobra Venom. Arch. Biochem. Biophys. 1973, 156, 71-76.

53. Hellman, K.; Miller, D. S.; Cammack, K. A. The Effect of Freeze-Drying on the Quaternary Structure of L-Asparaginase from Erwinia Carotovora. Biochim. Biophys. Acta, Protein Struct. Mol. Enzymol. 1983, 749, 133-142.

54. Prestrelski, S. J.; Arakawa, T.; Carpenter, J. F. Separation of Freezing- and Drying-Induced Denaturation of Lyophilized Proteins Using Stress-Specific Stabilization. Arch. Biochem. Biophys. 1993, 303, 465-473.

55. Burke, P. A.; Smith, S. O.; Bachovchin, W. W.; Klibanov, A. M. Demonstration of Structural Integrity of an Enzyme in Organic Solvents by Solid-State NMR. J. Am. Chem. Soc. 1989, 111, 8290-8291.

56. Careri, G.; Gratton, E.; Yang, P. H.; Rupley, J. A. Correlation of IR Spectroscopic, Heat Capacity, Diamagnetic Susceptibility and Enzymatic Measurements on Lysozyme Powder. Nature 1980, 284, 572573.

57. Schinkel, J. E.; Downer, N. W.; Rupley, J. A. Hydrogen Exchange of Lysozyme Powders. Hydration Dependence of Internal Motions. Biochemistry 1985, 24, 352-366.

58. Ikeda, K.; Egawa, A.; Fujiwara, T. Secondary Structural Analysis of Proteins Based on ${ }^{13} \mathrm{C}$ Chemical Shift Assignments in Unresolved Solid-State NMR Spectra Enhanced by Fragmented Structure Database. J. Biomol. NMR 2013, 55, 189-200. 
Table of Contents Graphic

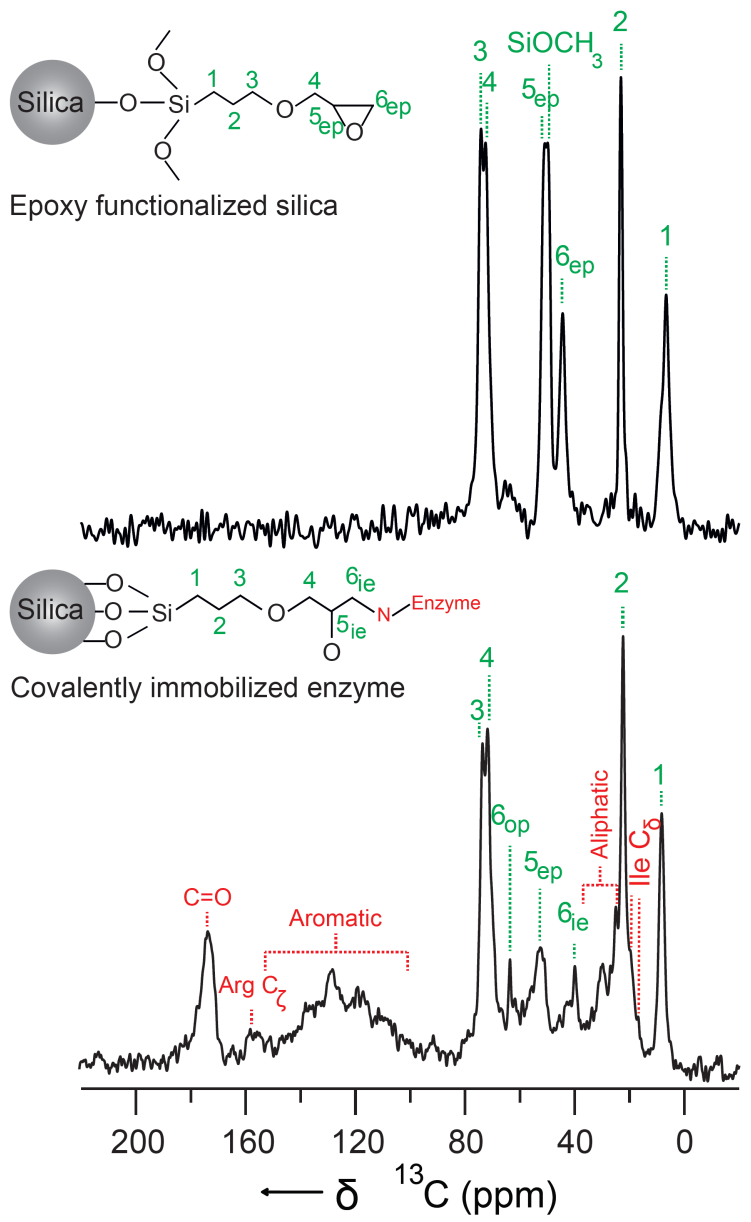




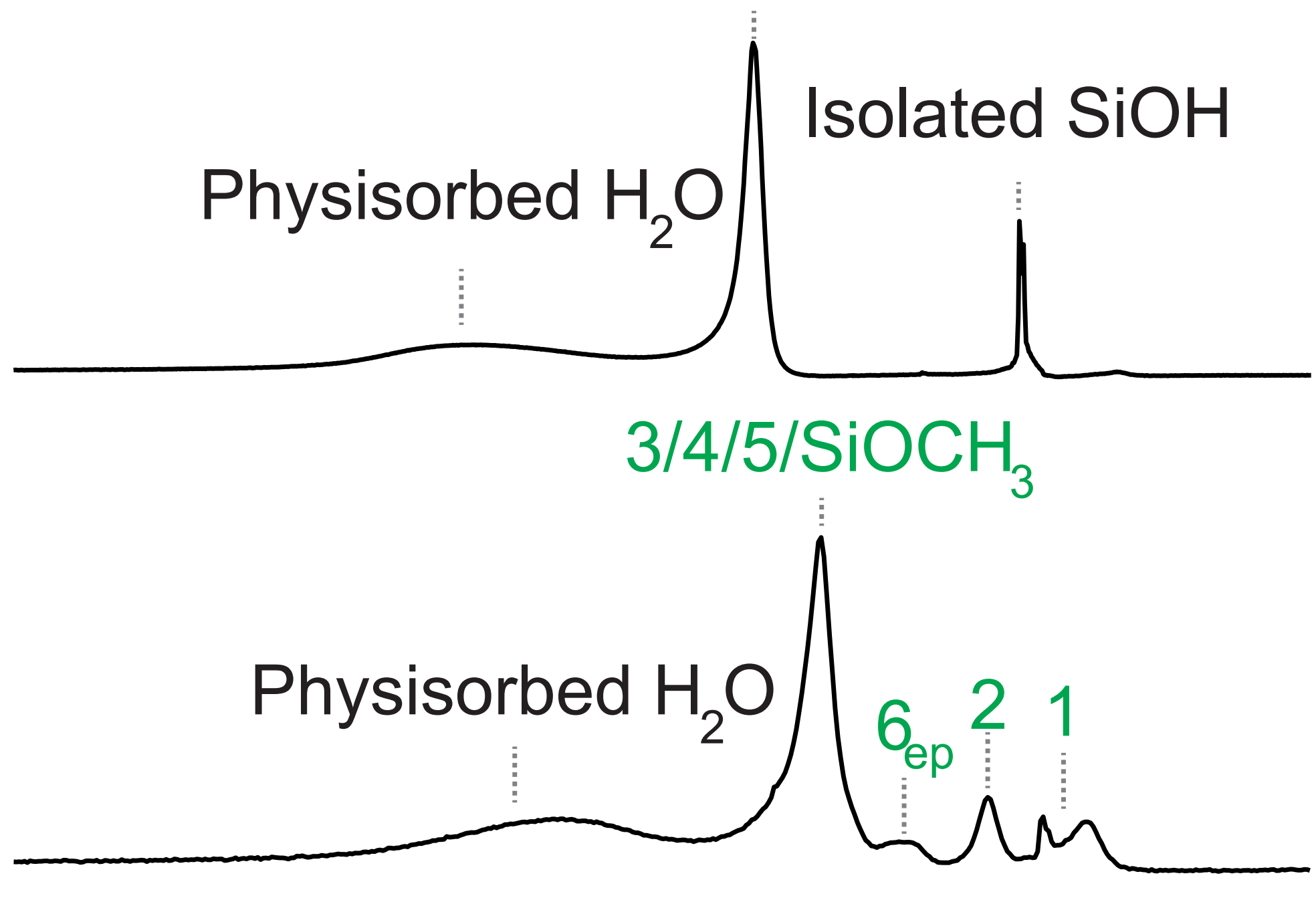

$\mathrm{H}_{2} \mathrm{O}$

Aliphatic

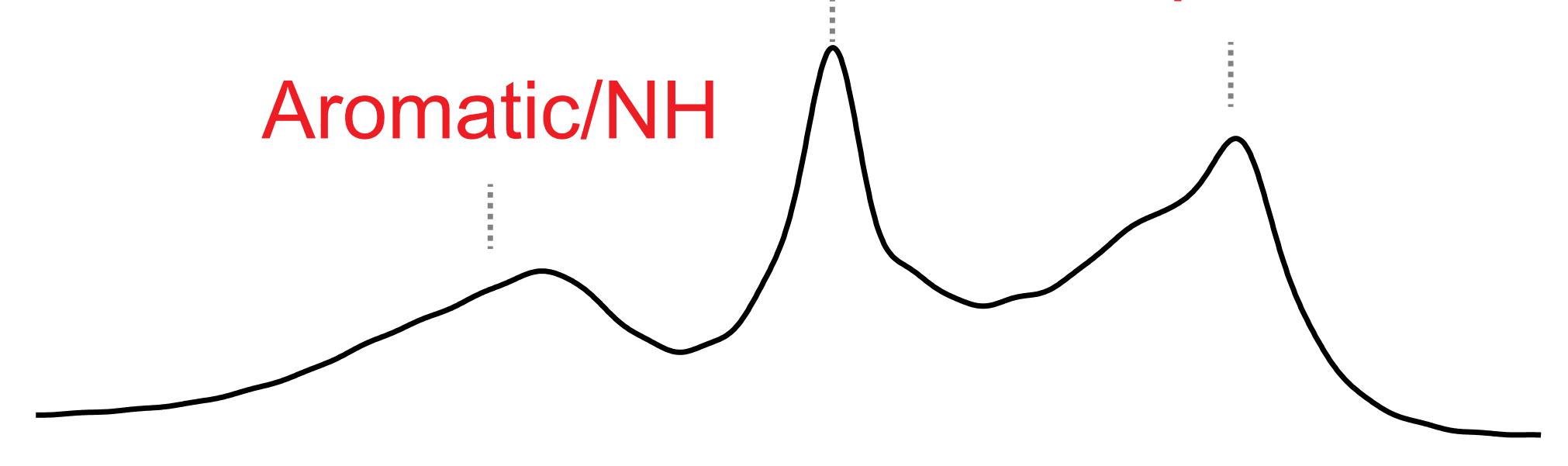

$\mathrm{H}_{2} \mathrm{O}$

Aliphatic

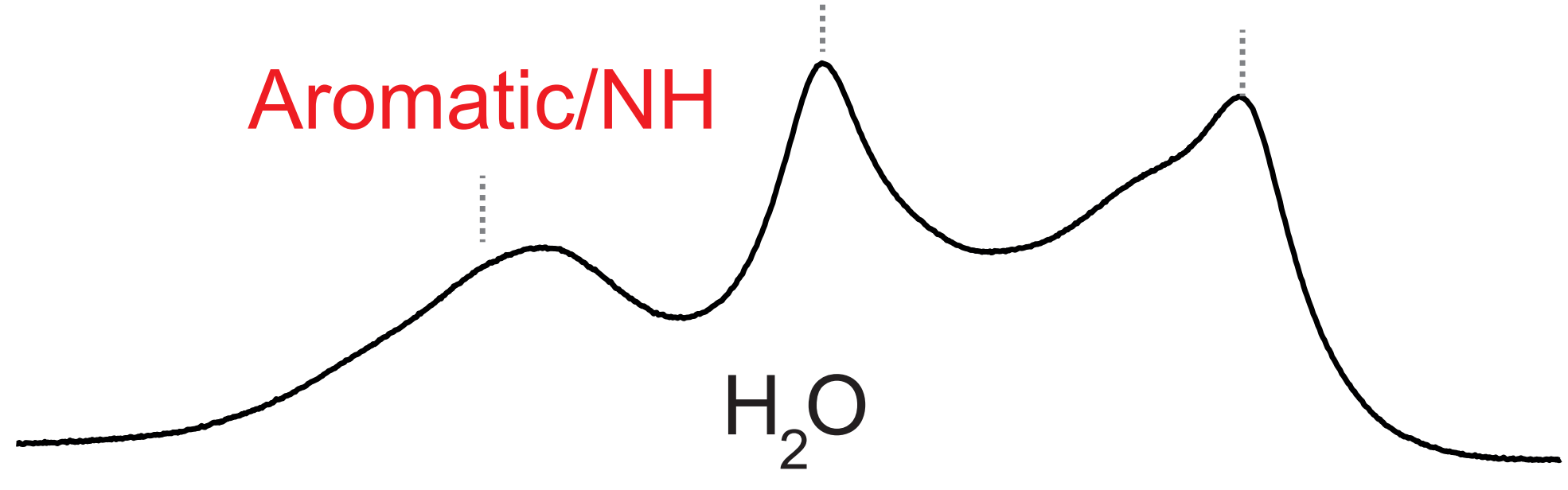

(e)

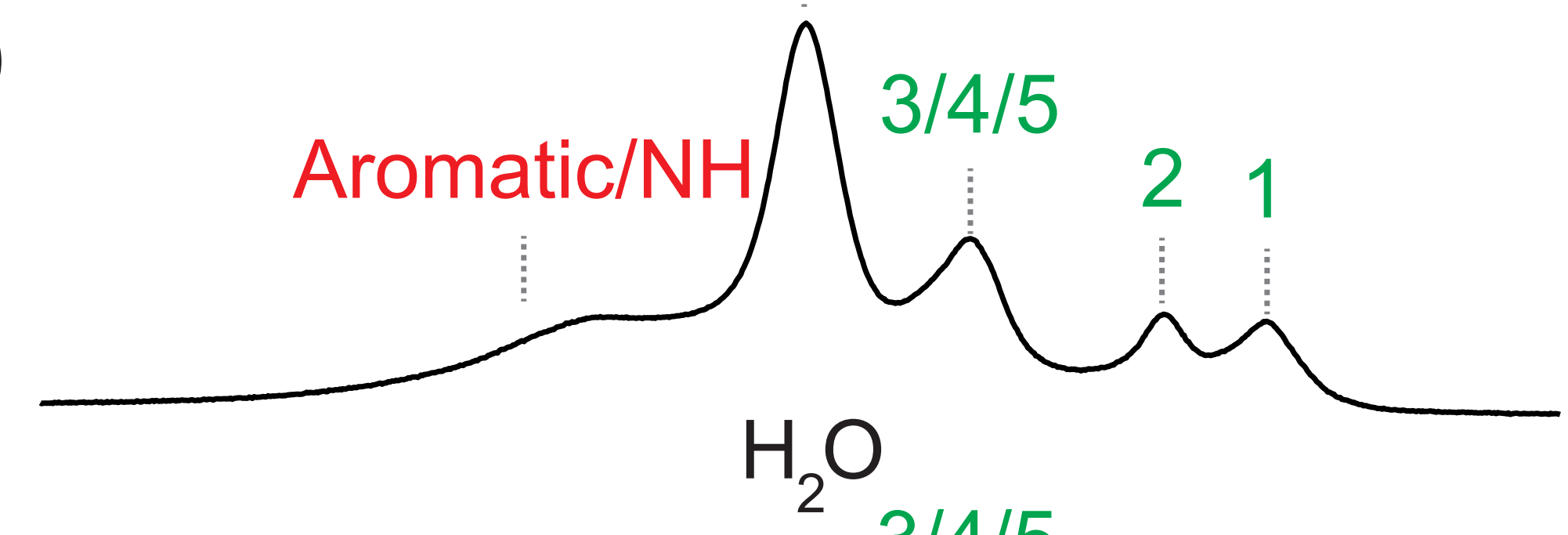

(f)

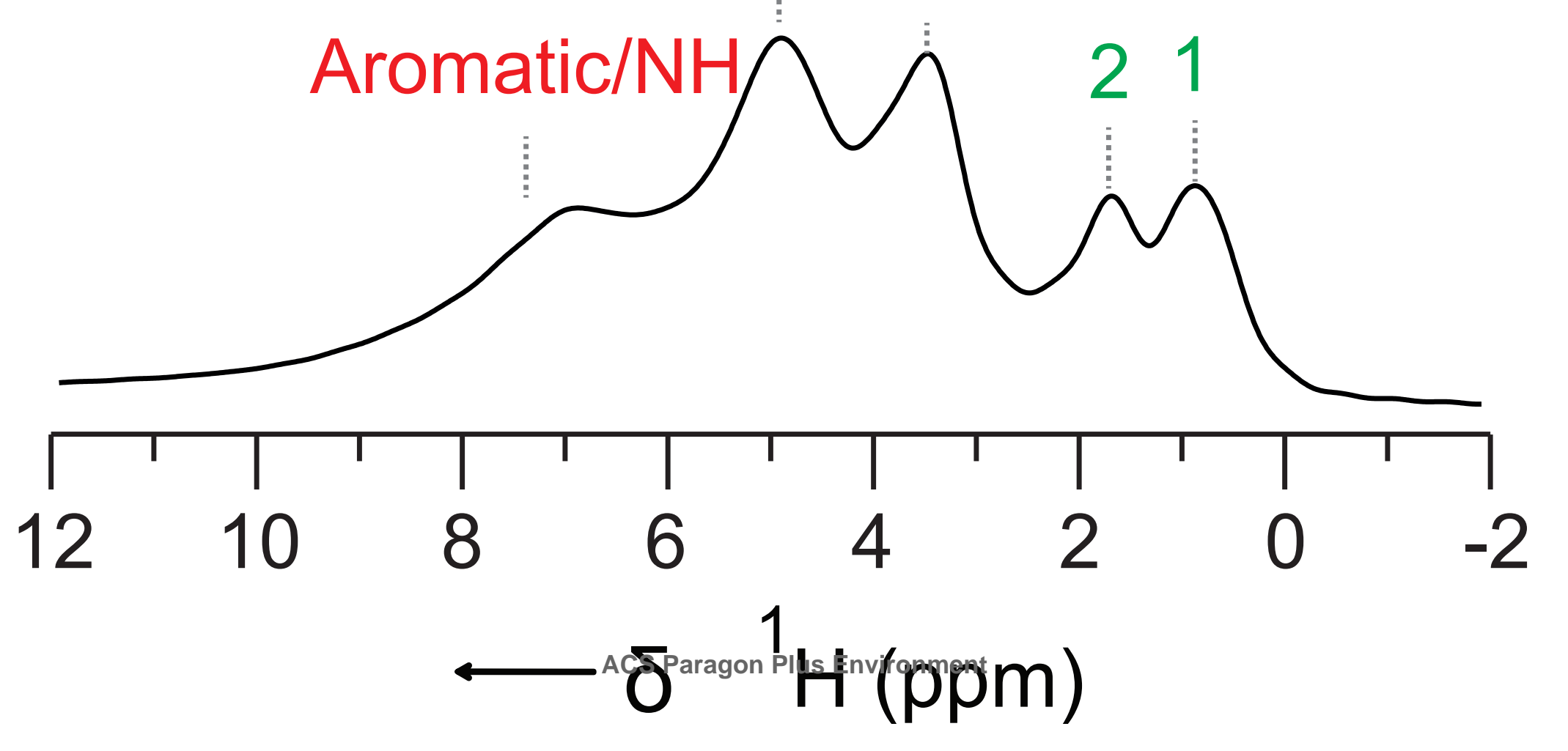




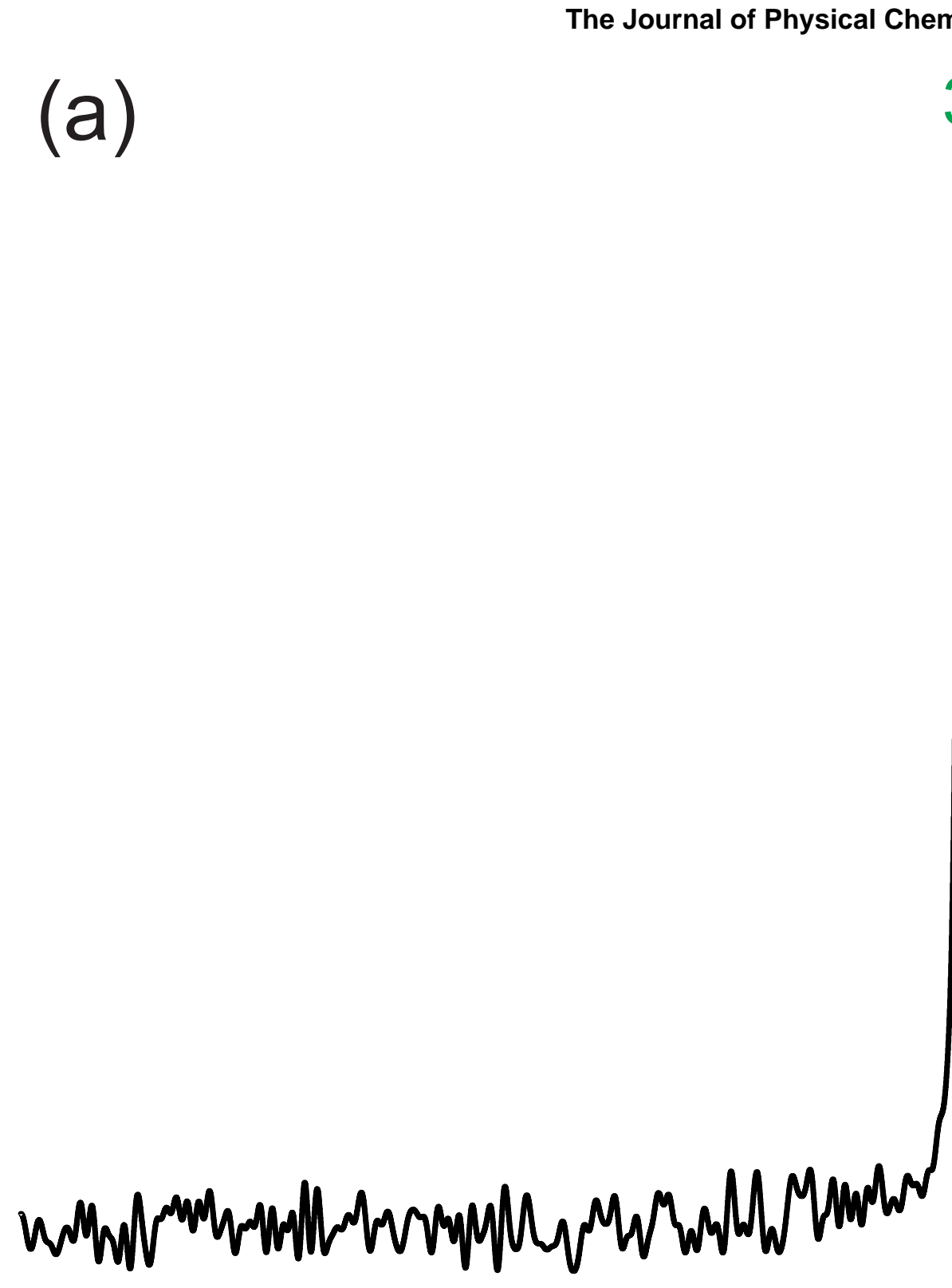

Page 12 of 16

1
2
3
4
5
6
7
8
9
10
11
12
13
14
15
16
17
18
19
20
21
22
23
24
25
26
27
28
29
30
31
32
33
34
35
36
37
38
39
40
41
42
43
44
45
46
47
48
49
50
51
52
53
54
55
56
57
58
59
60

$3 \mathrm{SiOCH}_{3}$

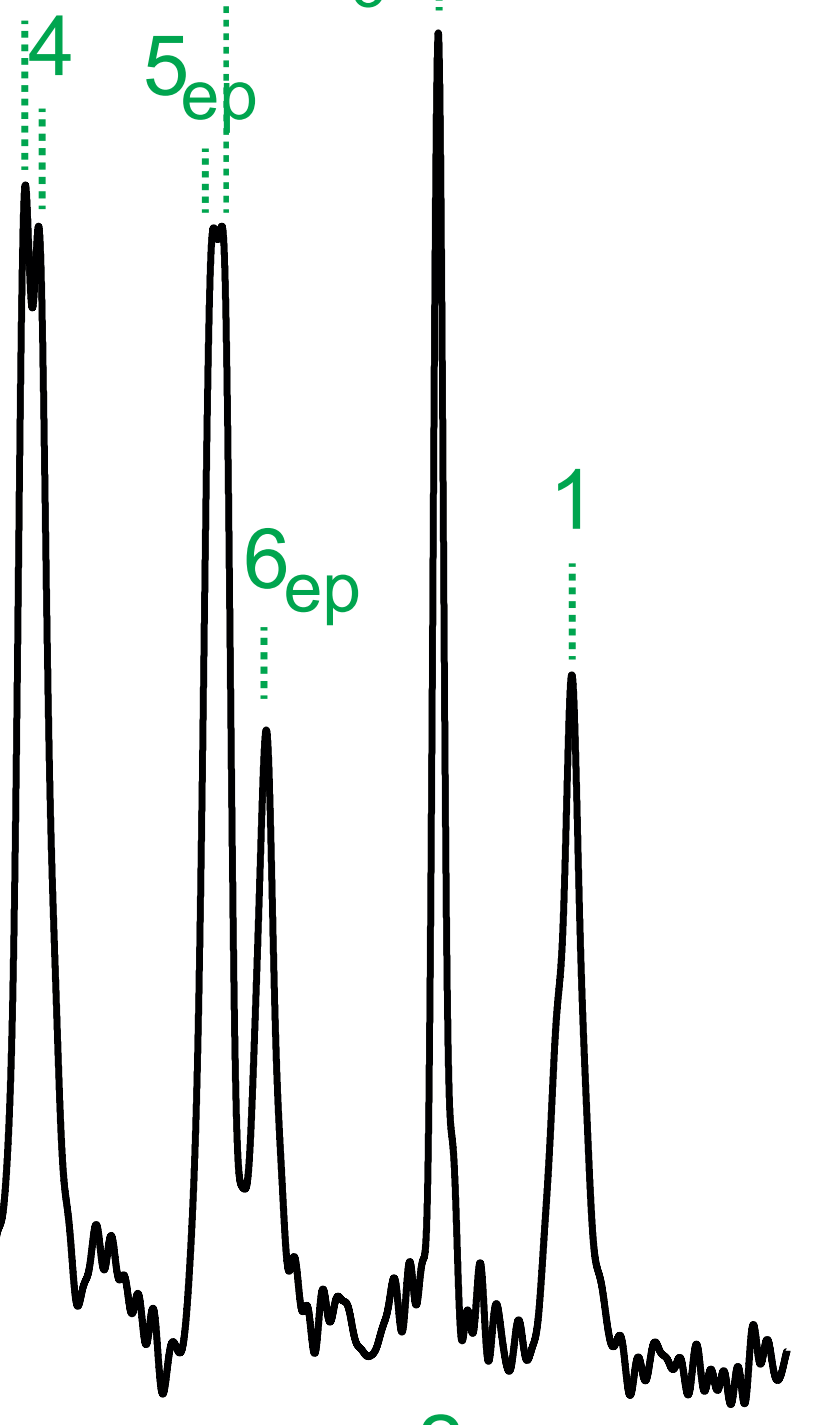

2

(b)

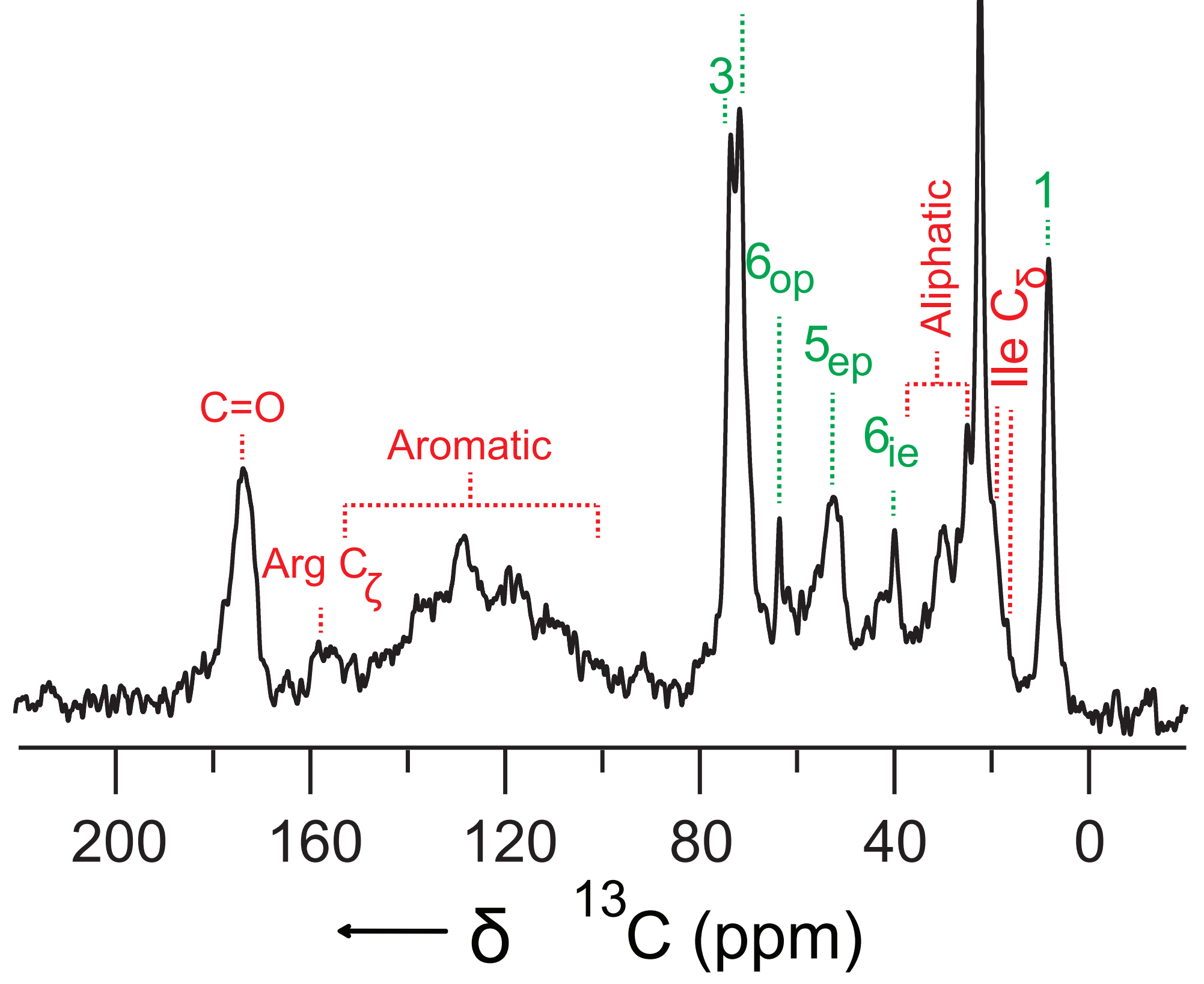

ACS Paragon Plus Environment 
(a)

(b)
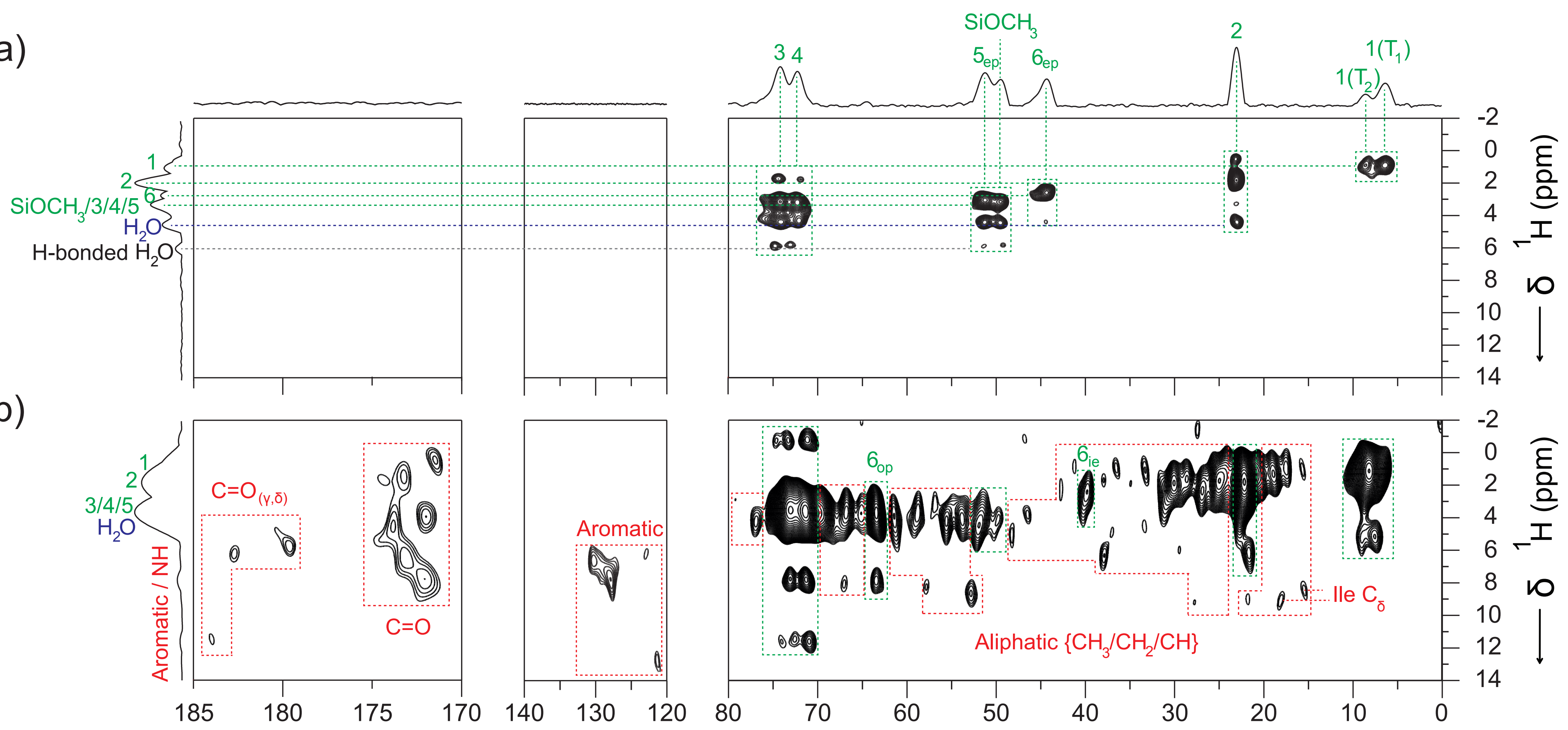

(c)

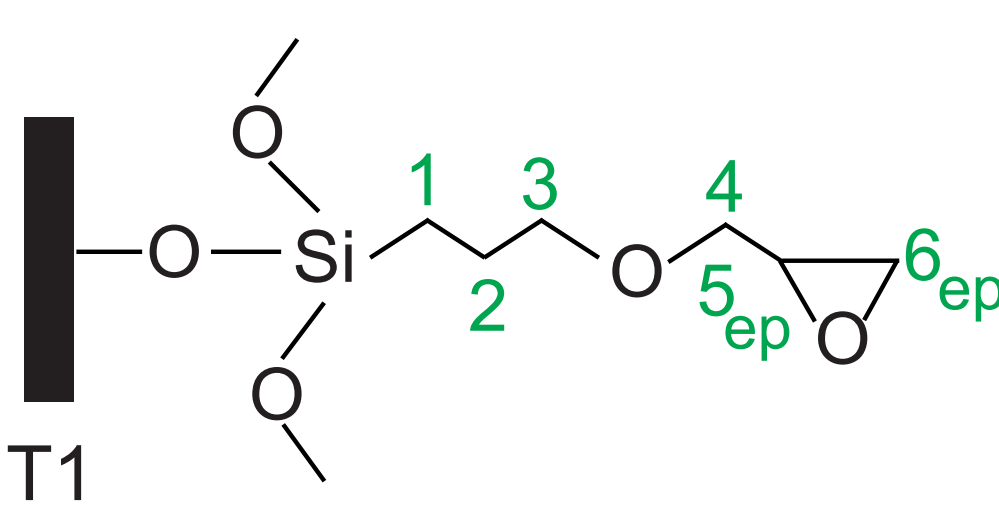

ep: epoxy-ring

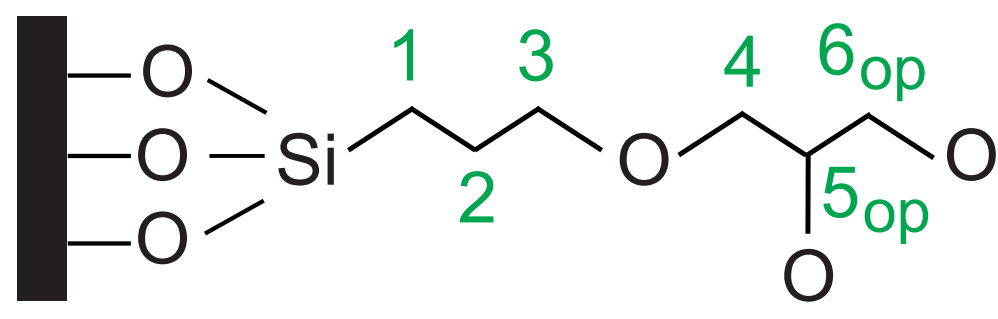

T3
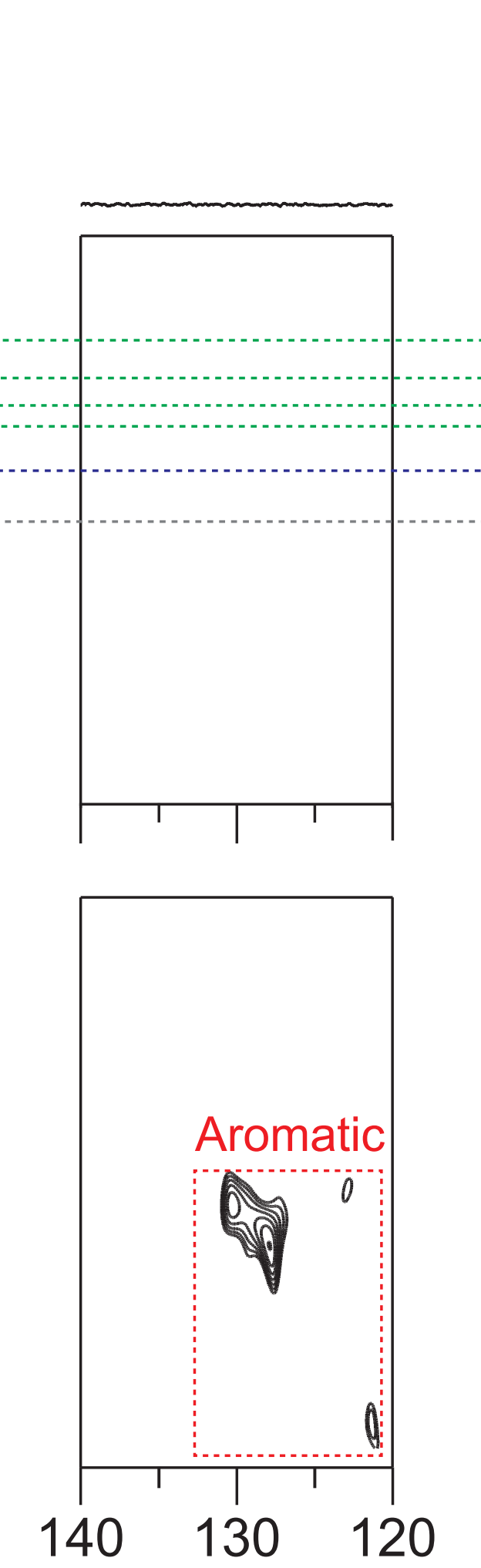

$\longleftarrow \delta{ }^{13} \mathrm{C}(\mathrm{ppm})$

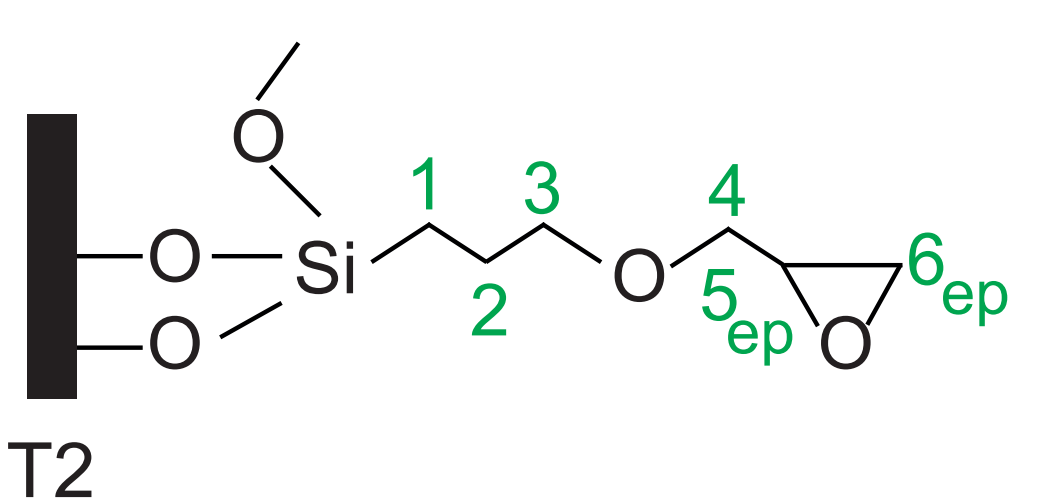

op: open epoxy-ring

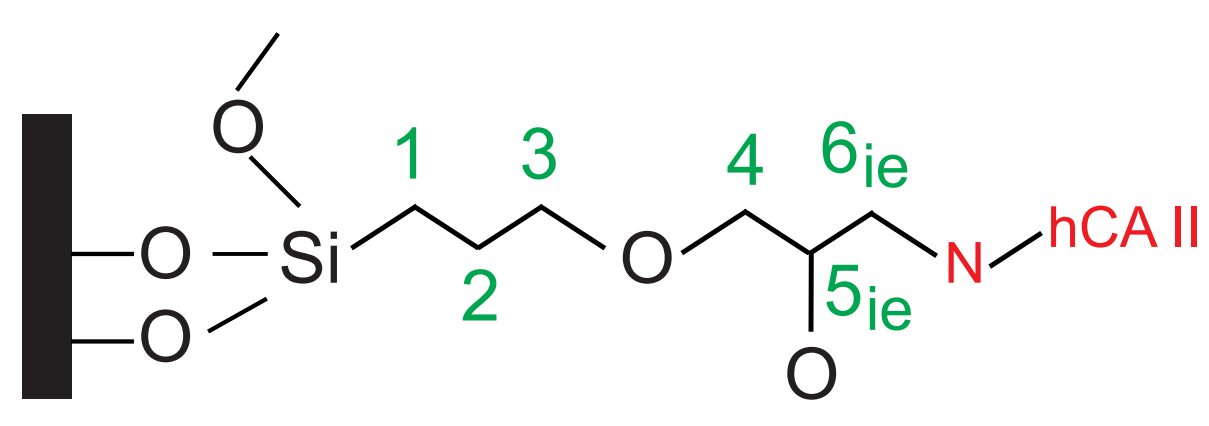

T2

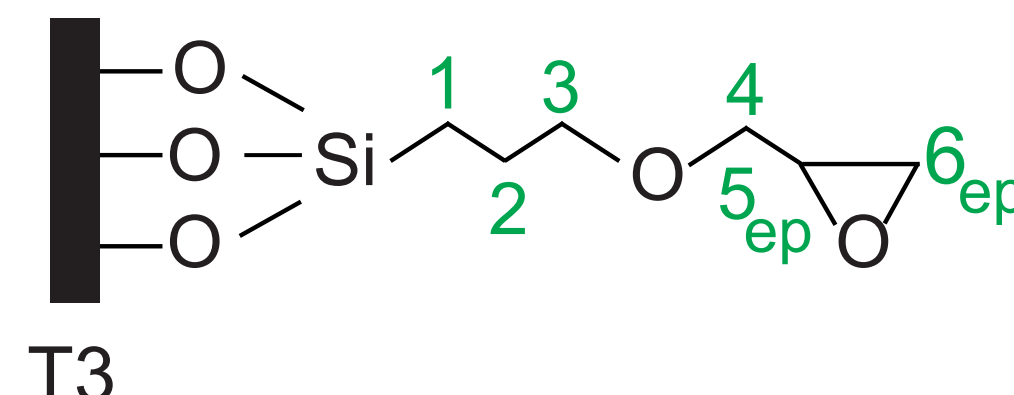

ie: immobilized enzyme

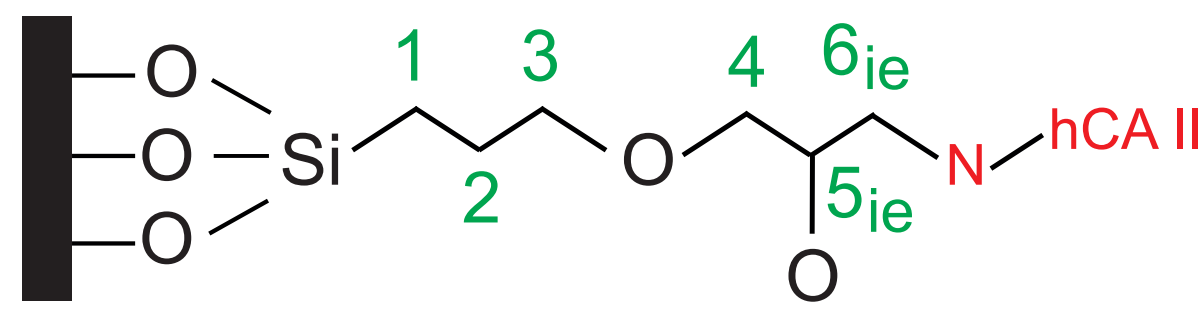

T3 
(a)
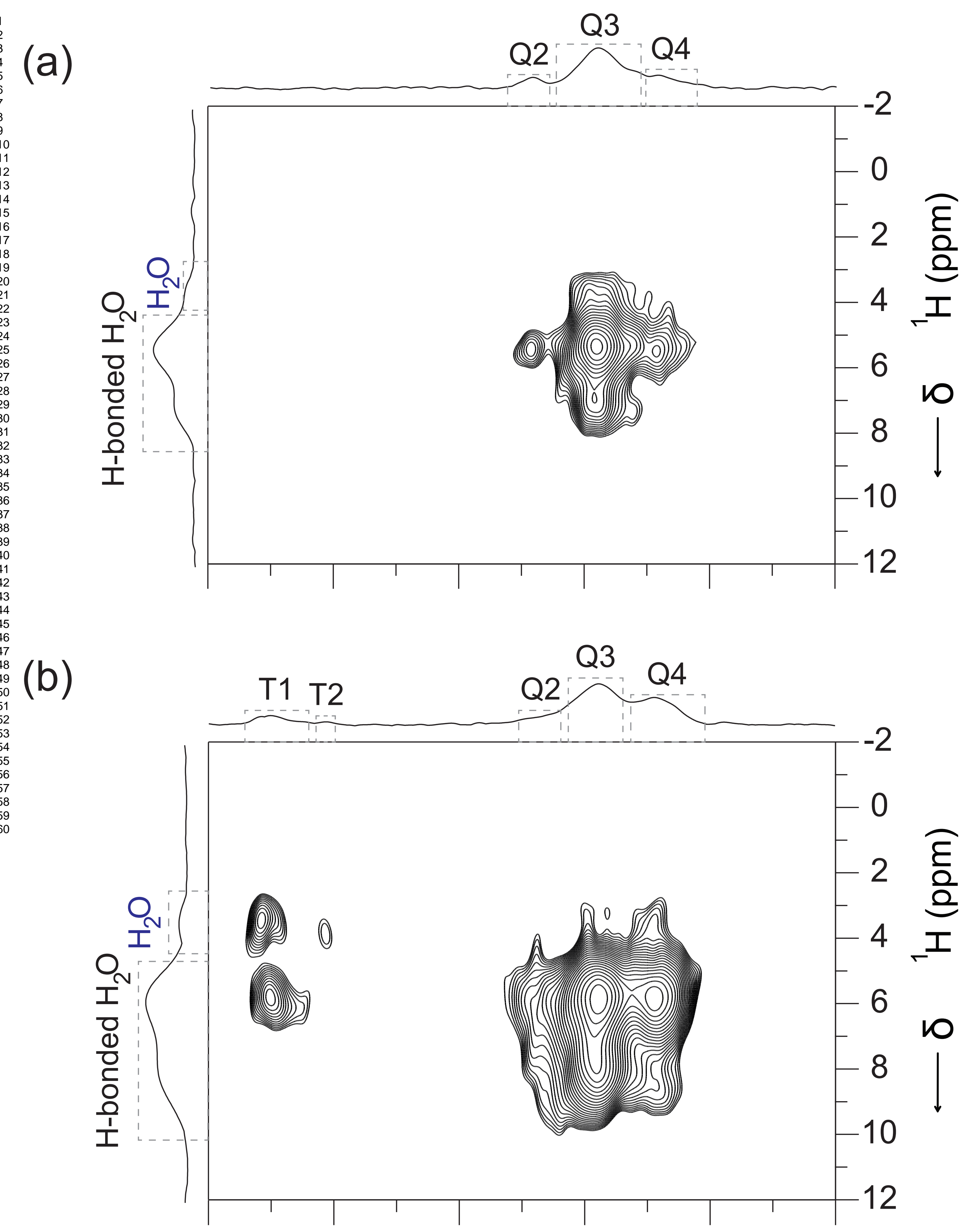

(c)

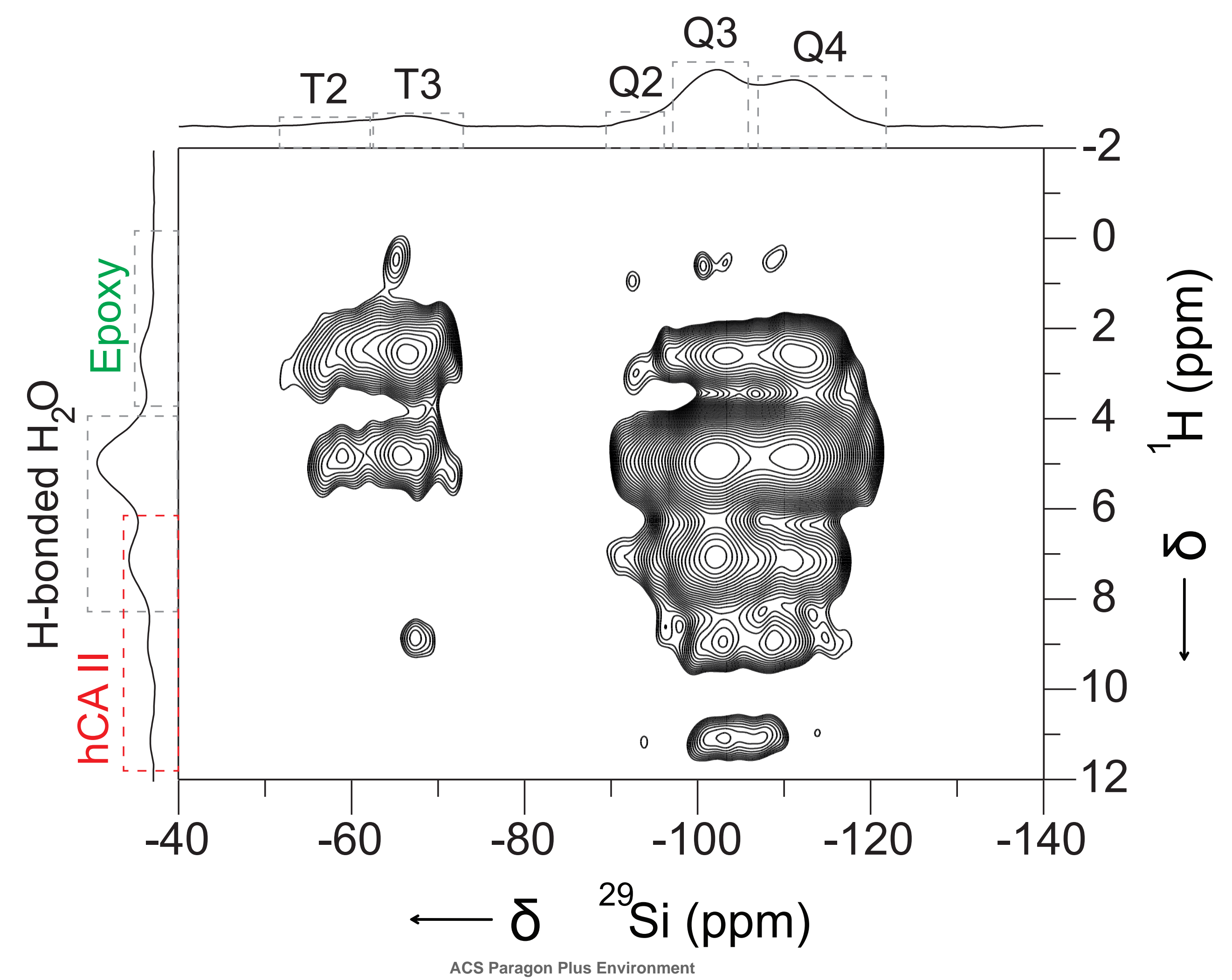




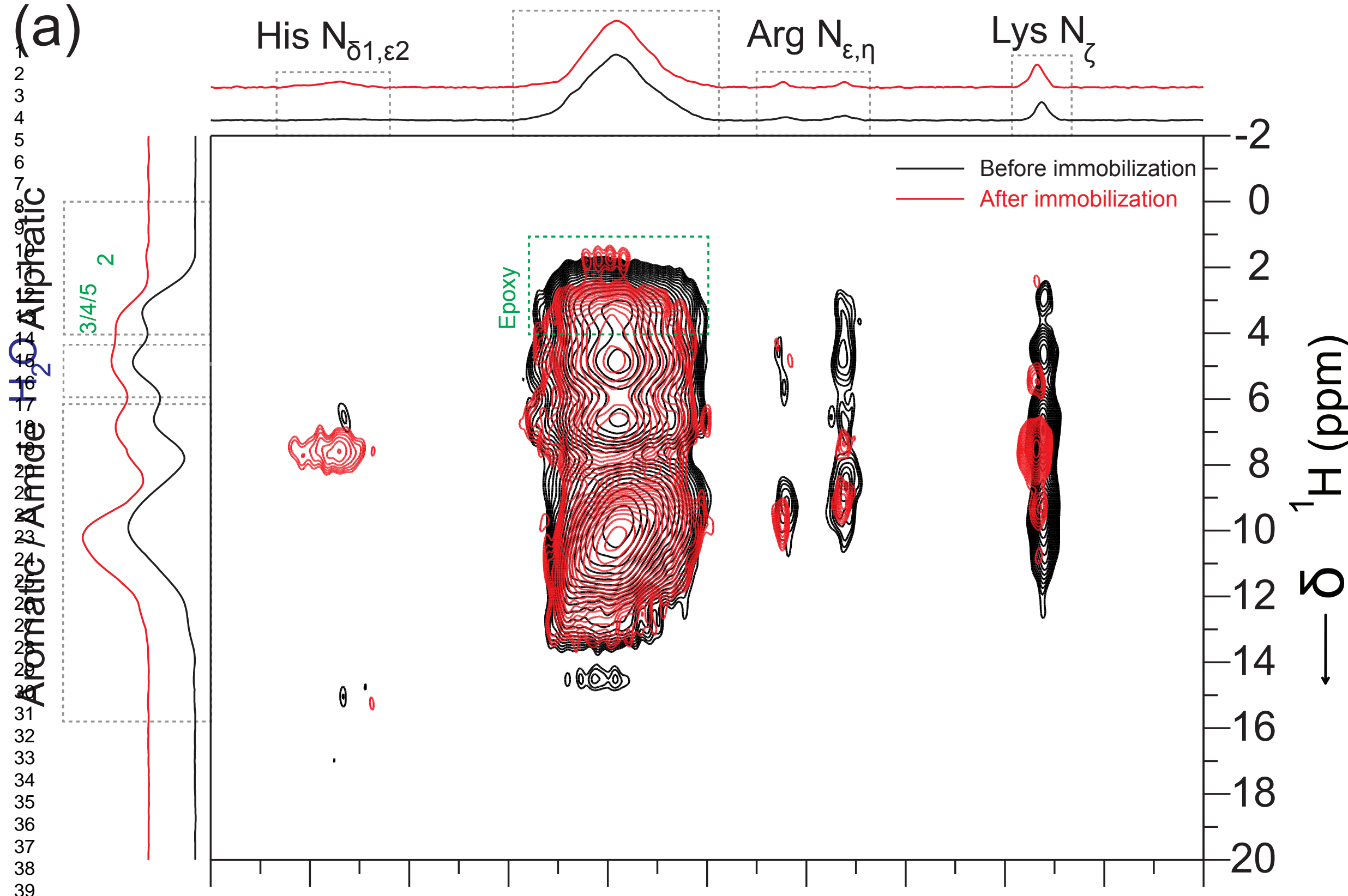

Backbone amide
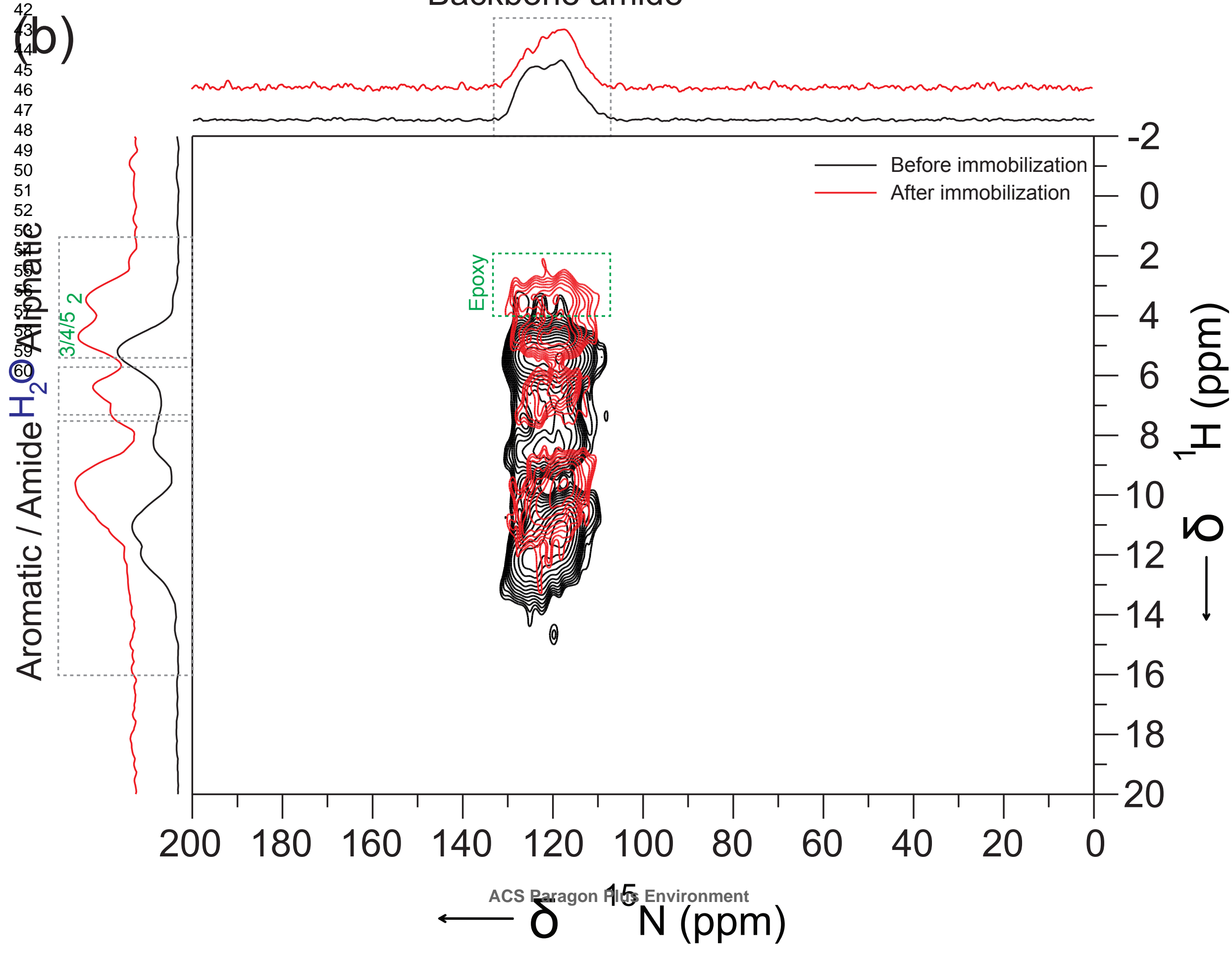

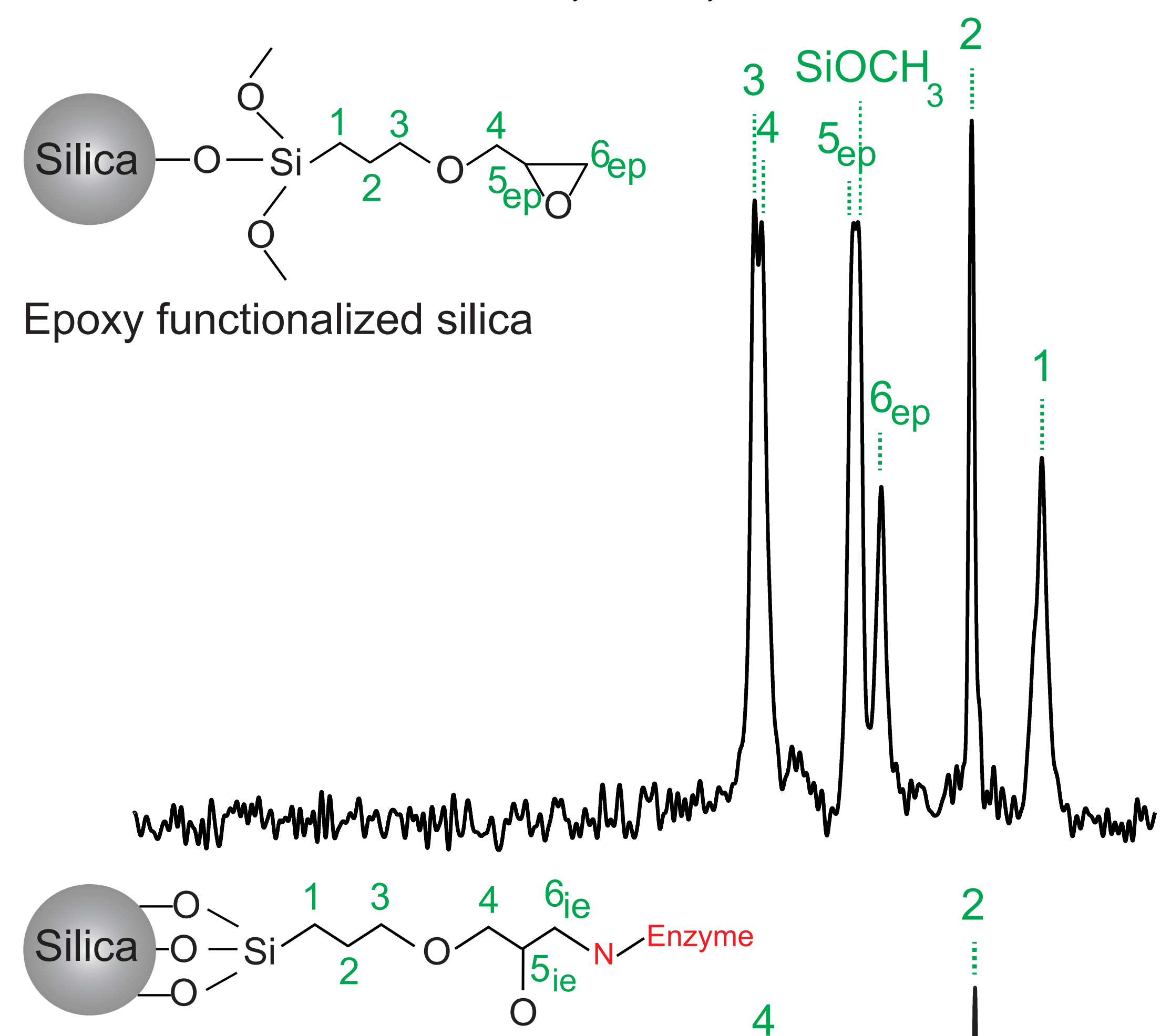

Covalently immobilized enzyme

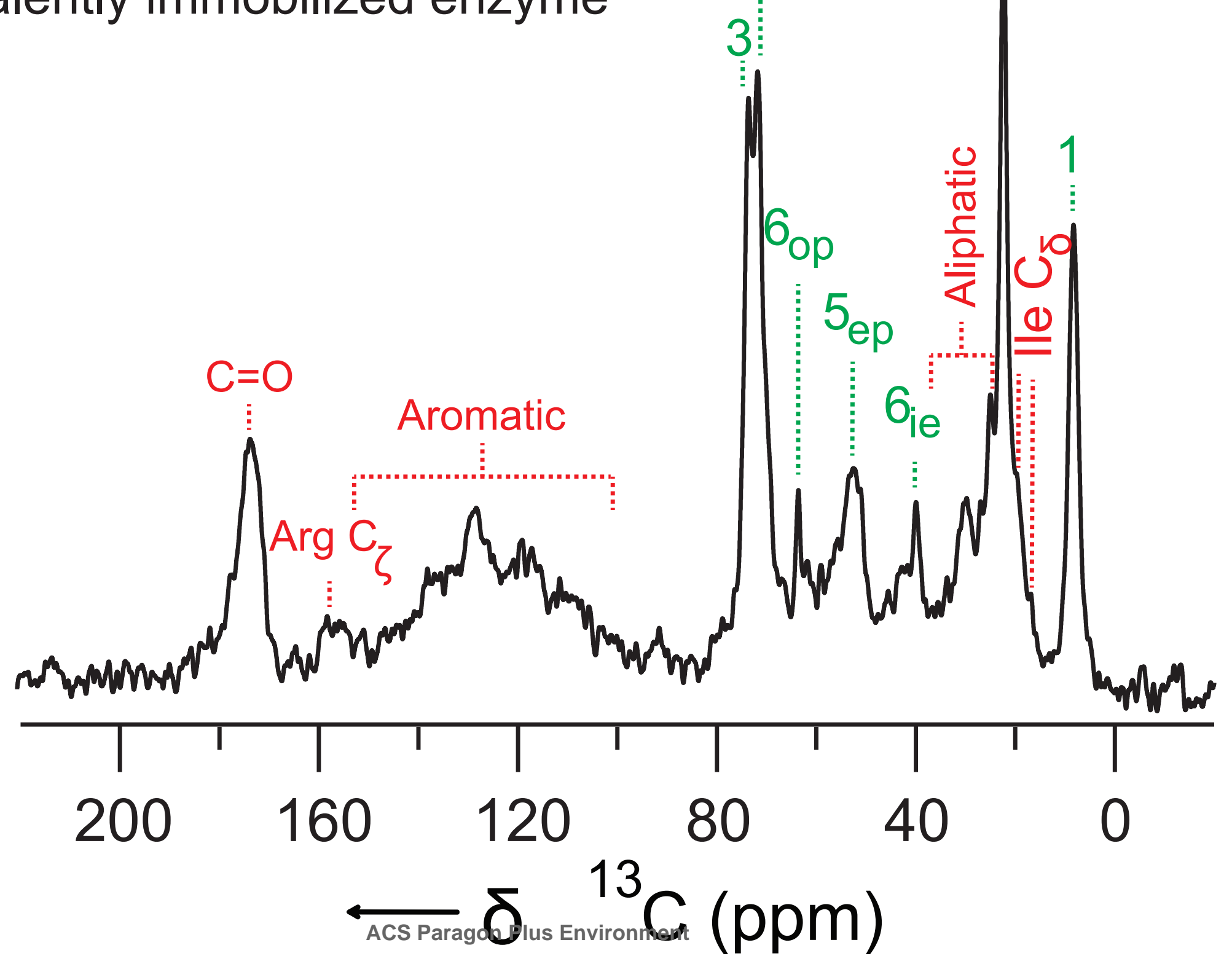

